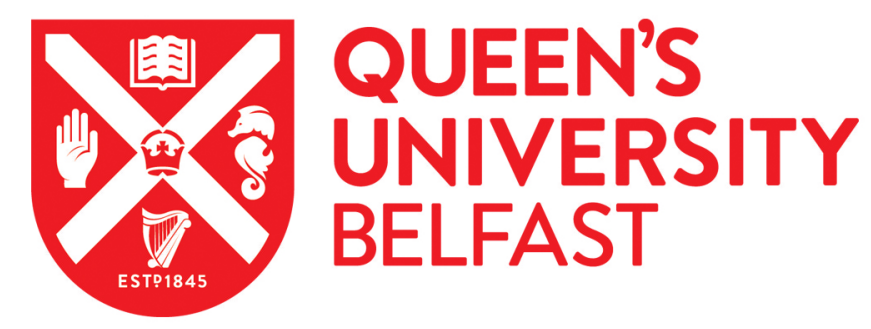

\title{
Hydroclimate variability of central Indo-Pacific region during the Holocene
}

Chawchai, S., Tan, L., Löwemark, L., Wang, H-C., Yu, T-L., Chung, Y-C., Mii, H-C., Liu, G., Blaauw, M., Gong, S-Y., Wohlfarth, B., \& Shen, C-C. (2021). Hydroclimate variability of central Indo-Pacific region during the Holocene. Quaternary Science Reviews, 253. https://doi.org/10.1016/j.quascirev.2020.106779

\author{
Published in: \\ Quaternary Science Reviews
}

\section{Document Version:}

Peer reviewed version

\section{Queen's University Belfast - Research Portal:}

Link to publication record in Queen's University Belfast Research Portal

\section{Publisher rights}

Copyright 2021 Elsevier.

This manuscript is distributed under a Creative Commons Attribution-NonCommercial-NoDerivs License

(https://creativecommons.org/licenses/by-nc-nd/4.0/), which permits distribution and reproduction for non-commercial purposes, provided the author and source are cited.

\section{General rights}

Copyright for the publications made accessible via the Queen's University Belfast Research Portal is retained by the author(s) and / or other copyright owners and it is a condition of accessing these publications that users recognise and abide by the legal requirements associated with these rights.

Take down policy

The Research Portal is Queen's institutional repository that provides access to Queen's research output. Every effort has been made to ensure that content in the Research Portal does not infringe any person's rights, or applicable UK laws. If you discover content in the Research Portal that you believe breaches copyright or violates any law, please contact openaccess@qub.ac.uk. 


\section{Quaternary Science Reviews \\ Hydroclimate variability of central Indo-Pacific region during the Holocene --Manuscript Draft--}

Manuscript Number:

Article Type:

Keywords:

Corresponding Author:

First Author:

Order of Authors:

Abstract:

Suggested Reviewers:
JQSR-D-20-00385R1

Research Paper

Stalagmite; Thai-Malay Peninsula; Holocene; ITCZ; central Indo-Pacific region

Sakonvan Chawchai

Chulalongkorn University Faculty of Science

Bangkok, THAILAND

Sakonvan Chawchai

Sakonvan Chawchai

Liangcheng Tan, Professor

Ludvig Löwemark, Professor

Hao-Cheng Wang

Tsai-Luen Yu

Yun-Chuan Chung

Horng-Sheng Mii, Professor

Guangxin Liu, Dr.

Maarten Blaauw, Professor

Shou-Yeh Gong, Dr.

Barbara Wohlfarth, Professor

Chuan-Chou Shen, Professor

Here we present a decadal-resolved hydroclimate record covering the past 11 thousand years based on $\delta 18 \mathrm{O}$ data of three stalagmites from Klang Cave (TK) on the Thai-Malay Peninsula, southern Thailand. The $\delta 18 \mathrm{O}$ values indicate wetter conditions/more rainfall during the early Holocene from 11 to 7 thousand years before present (kyr BP). A I arge increase of $2 \%$ in $\delta 18 \mathrm{O}$ is observed from 7.0 to $6.0 \mathrm{kyr}$ $\mathrm{BP}$, indicating a millennial drying period followed by drought conditions between 6.0 and $5.2 \mathrm{kyr}$ BP. After a long hiatus ( $5.2-2.7 \mathrm{kyr}$ BP), d $18 \mathrm{O}$ data show a millennium-long trend toward dry conditions. An abrupt positive change of $0.8-1.0 \%$ in $\delta 18 \mathrm{O}$ is noticed between $8.29-8.17 \mathrm{kyr} \mathrm{BP}$, reflecting the 8.2-ka event, however; the amplitude of the $\delta 18 \mathrm{O}$ shift is much smaller when compared to $6.0-5.2 \mathrm{kyr} \mathrm{BP}$. On orbital time-scales , the TK record agrees with insolation-dominated speleothem records in the Asian-Australian monsoon realm. Noticeable inconsistencies among records in the Southeast Asia region (between $8^{\circ} \mathrm{N}$ and $4^{\circ} \mathrm{N}-8^{\circ} \mathrm{S}$ ) have been documented on multi-centennial scales. L ower $\delta 18 \mathrm{O}$ values are likely associated with the mean position of the Intertropical Convergence Zone (ITCZ). A new reconstruction of Holocene ITCZ shifts index within the central Indo-Pacific region, based on stalagmite $\delta 18 \mathrm{O}$ records from Klang Cave $\left(8^{\circ} \mathrm{N}\right)$ and Liang Luar Cave $\left(8^{\circ} \mathrm{S}\right)$, shows that the ITCZ played an important role in hydroclimate variability in the Asian-Australian monsoon regions. The southward shift of the ITCZ in the central IndoPacific region, controlled by the interhemispheric extratropical insolation gradient, may strongly correlate with the El Niño-Southern Oscillation (ENSO) activities in the Holocene.

Judson W. Partin

Professor, University of Texas at Austin

jpartin@ig.utexas.edu

Experts in Speleothem and climate dynamic in the pacific regions and on a wide range of topics related to paleoclimate change. 
Professor, Chinese Academy of Sciences

yanjun_cai@ieecas.cn

Experts in Speleothem and paleoclimate in Asian Monsoon regions.

John C. H. Chiang

University of California Berkeley

jch_chiang@berkeley.edu

Experts in climate dynamics of the global atmosphere and its interactions with the ocean and land systems.

Xianfeng Wang

Professor, Nanyang Technological University

xianfeng.wang@ntu.edu.sg

Experts in Speleothem, isotopes geochemistry and climate dynamics of Southeast Asia

Ashish Sinha

Professor, California State University Dominguez Hills

asinha@usc.edu

Experts in speleothem isotope geochemistry, past climate dynamics on sociallyrelevant time scales.

Response to Reviewers: 
Quaternary Science Reviews: manuscript JQSR-D-20-00385

Dear Editor, Dr. Miryam Bar-Matthews,

We would like to express our appreciation to the editor Dr. Miryam Bar-Matthews for handling our manuscript and for the positive comments and for summarizing issues raised by the reviewers. We also thank two anonymous reviewers for their professional and constructive comments and suggestions. We have addressed the Editor's and all reviewers' concerns, rewritten, and made the changes to our manuscript. In the appendix, we list all the reviewers' questions and comments, together with our responses highlighted in blue.

Please find enclosed our revised manuscript. We very much hope that it is acceptable for publication in Quaternary Science Reviews. We declare that this manuscript is original, not published, in press, or submitted elsewhere.

Thank you very much again for handling the reviewing process of our manuscript. Should you have any questions, please do not hesitate to contact us.

Your Sincerely,

Sakonvan Chawchai, Chuan-Chou Shen (Corresponding Authors) 
Quaternary Science Reviews: manuscript JQSR-D-20-00385

Editor and Reviewer comments:

\section{Response to editor and reviewers's comment in Blue.}

Dear Editor, Dr. Miryam Bar-Matthews,

We would like to express our appreciation to the editor Dr. Miryam Bar-Matthews for handling our manuscript and for the positive comments and for summarizing issues raised by the reviewers. We also thank two anonymous reviewers for their professional and constructive comments and suggestions. We have addressed the Editor's and all reviewers' concerns, rewritten, and made the changes to our manuscript. In the appendix, we list all the reviewers' questions and comments, together with our responses highlighted in blue.

Please find enclosed our revised manuscript. We very much hope that it is acceptable for publication in Quaternary Science Reviews. We declare that this manuscript is original, not published, in press, or submitted elsewhere.

Thank you very much again for handling the reviewing process of our manuscript. Should you have any questions, please do not hesitate to contact us.

Your Sincerely,

Sakonvan Chawchai, Chuan-Chou Shen (Corresponding Authors) 


\section{Editor comments}

E1. Chawchai et al. presents a speleothem $\delta 180$ records spanning most of Holocene from Klang Cave in Thai-Malay Peninsula, southern Thailand, which follow the study by Tan et al. (2019, PNAS). In this study the authors extended the record, for most of the last 11,000 years by using different aragonitic stalagmites which covering the different time periods. The major findings include broad similarity with other speleothem-based monsoon records mostly in East Asia; a millennial drought period in the middle Holocene; identifying the 8.2-ka event in the tropical Indo-Pacific region and reconstructing the ITCZ shift index during the Holocene. The quality of the data is very good, the subject addressed is worthy of investigation, the information presented is new and worthy publication in QSR. The new record is important for understanding the Holocene hydroclimate changes in tropical Indo-Pacific region.

Reply: Thank you for this positive comment.

E2. However, the two reviewers and I found some important problems that need to be addressed before the manuscript can be accepted for publication. I will summarize the most important points:

E3. The manuscript is missing discussion on the petrography of the samples, are there evidence to changes in growth pattern associated with shifts in d180?

Reply: We did XRD analysis to show all three stalagmites, TK7, TK20, and TK40, are aragonite. For TK 7, one dark layer is observed at a depth of $21 \mathrm{~mm}$ (Fig. R1). U-Th ages at two depths above and below the layer show that this dark layer is a hiatus. For TK20 and TK40, stalagmites are quite clean and show aragonite texture. We wrote "X-ray diffraction (XRD) analysis at 6 depths (Supplementary Data Fig. 1) show that all stalagmites are composed of pure aragonite without mineral transformation." (Lines 166-168) and "Two UTh ages of $2758 \pm 20$ and $5255 \pm 37 \mathrm{yr}$ BP at depths of 18 and $28 \mathrm{~mm}$ of stalagmite TK7 indicate that a dark layer at $21 \mathrm{~mm}$ is a hiatus (Supplementary Data Fig. 1)." (Lines 213-215)

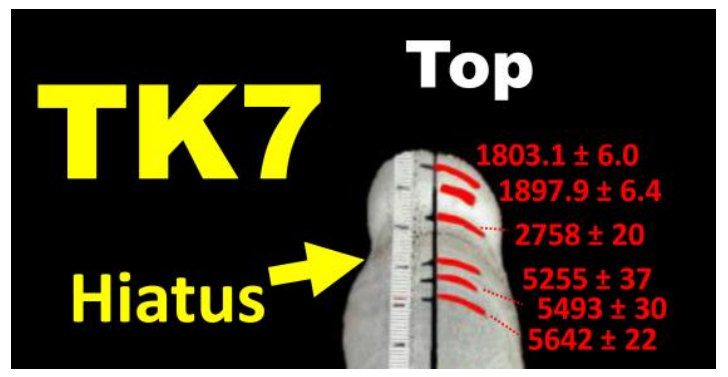

Fig. R1. The top segment of stalagmite TK7. One discountinous layer is observed at a depth of 21 $\mathrm{mm}$ from top. It is confirmed as a histus by using at depths above and below the layer.

E4. Can the author explain the hiatus between 5-3 ka, is it climatic driven or sampling bias?

Reply: We attempted to find any stalagmite samples covering 5-3 ka from all of our collected 46 stalagmites. However, we could not find any stalagmites filling this gap between 5-3 ka. The recent study of Griffiths et al. (2020) shows drought evidence during the mid-Holocene in speleothem from Laos. We cannot fully rule out the possibility that the hiatus is resulting from a prolonged drought. We wrote "A recent study of stalagmite $\delta^{18} O$ from Laos indicated megadrought in Mainland Southeast Asia between 5 and $3 \mathrm{kyr}$ BP (Griffiths et al., 2020), which could be the possible reason of the observed hiatus at 5.23-2.73 kyr BP in the Klang Cave records (Figs. 2, 4C)." (Lines 339-342) 
E5. Although there is a small peak that may be related to the $8.2 \mathrm{ka}$ event, there are other events in the same magnitude that are not discussed. Is indeed the 8.2 event is so significant. The event from $\sim 6.0$ to $5.4 \mathrm{ka}$ is be far more prominent. Can the authors explain what drove the 8.2 event in this location?

Reply: We agreed with the editor that compared to the period from $\sim 6.0$ to $5.4 \mathrm{ka}$, the $8.2 \mathrm{ka}$ event in Klang record is less prominent. However, the identification of $8.2 \mathrm{ka}$ event at our location bears its own climate significance. Our Klang Cave record, for the first time to our knowledge, provides strong evidence that the impact of 8.2-ka event can reach the tropical Indo-Pacific.

Regarding what drove the $8.2 \mathrm{ka}$ event in our location, we have invoked the well-accepted mechanism for this teleconnection, i.e., through the weakening of AMOC and consequently the southward shift of the ITCZ (Lines 233-240 in the original submission). For clarity, we revised the related discussion to "It has been attributed to the last outburst flood from glacial Lake Agassiz, (Clarke et al., 2004; Lajeunesse and St-Onge, 2008; Teller et al., 2002), which freshened North Atlantic surface waters, reduced the production of North Atlantic Deep Water and weakened the North Atlantic Meridional Overturning Circulation (AMOC). A weakened AMOC hindered the northward transportation of warm surface waters, caused a southward shift of the ITCZ and reduced Asian monsoon (Cheng et al., 2009; Tan et al., 2020), and consequently a reduction of rainfall at our cave site, which led to a positive shift of $\delta^{18} \mathrm{O}$ in our stalagmite record." (Lines 295-303)

Nevertheless, considering that the foci of the manuscript is to capture the broad picture of Holocene hydroclimate changes, and considering the comments and suggestions from the editor as well as the two reviewers, we lower down the tune regarding the identification of 8.2 ka event, and remove the word "First" in the sentence "First stalagmite record of 8.2-ka event in the tropical Indo-Pacific region" from Highlights.

E6. Tan et al. (2019) proposed the ITCZ shift index for the last 2700 years to understand shifts of ITCZ by using normalized speleothem $\delta 18 \mathrm{O}$ data to overcome the offset between $\mathrm{d} 18 \mathrm{O}$ of stalagmites. Can the authors explain why this method can be applied to much longer time scale? There is no overlapping between TK40 and any other stalagmites, thus can the authors explain how reliable the ITCZ index is in the early Holocene.

Can the authors be more specific on the position of the ITCZ index?

Reply: In Tan et al. (2009), we used modern (1983-2011 AD) cross-equatorial rainfall gradient between 2 sectors (Fig. S13 of Tan et al., 2009) in northern central Indo-Pacific (NCIP) and southern CIP (SCIP) observations to show the meridional ITCZ shift (Fig. S13 of Tan et al., 2019). Klang and Liang Luar Caves are in the NCIP and SCIP sectors, respectively (Fig. S13 of Tan et al., 2019). The reconstructed ITCZ shift index (ITCZ SI), based on Klang and Liang Luar Cave $\delta^{18} \mathrm{O}$ records, over the past 2 millennia. However, in the early Holocene, sea-level related regional topography are indeed one of the main factors controlling the hydroclimate change during this time period; even though the most important forcing is the insolation (Fig. 7C). We discussed sea-level related Sunda Shelf exposure in the revised manuscript on Lines 426-434. We wrote: "Hydroclimate changes based on $\delta^{18} \mathrm{O}$ record of Klang Cave in the western margin of WPWP are dominantly associated with the ISM (Tan et al., 2019). Substantial early to mid-Holocene decreases in $\delta^{18}$ O record of Liang Luar Cave are interpreted as an intensification of Australian-Indonesian summer monsoon rainfall in response to deglacial eustatic sea-level rise and flooding of the Sunda Shelf (Griffiths et al., 2009). This new regional ITCZ SI record (Fig. 7A) shows different trends than that of the Cariaco Basin Ti record from 11.0-7.0 kyr BP, especially around 11.0-9.5 kyr BP. This disagreement can likely be attributed to Sunda Shelf exposure due to sea level rise (Griffiths et al., 2009)." 
The Editor was correct. A small gap between TK20 and TK40 $\delta^{18} \mathrm{O}$ records was observed in the original manuscript. In the revised manuscript, we did one additional dating at a depth of $47.6 \mathrm{~cm}$ of TK20 and isotopic analyses at a depth interval of 46.4-47.8 cm at the lowermost bottom of TK20 to fill this gap. The uppermost TK $40 \delta^{18} O$ values of $-6.03 \%$ at $8.840 \mathrm{kyr}$ BP match the lowermost $\delta^{18} O$ values of TK20 between $8.840-8.878 \mathrm{kyr}$ BP. These agreements show the fidelity of the our reconstructed ITCZ SI record. We wrote "Systematic offsets between stalagmite $\delta 180$ records in Klang Cave were reported in Tan et al. (2019). Similar oxygen isotopic discrepancies are not noticeable in this study. $\delta^{18} O$ variations of TK7 replicate TK20 during 8.35-7.34 kyr BP and show similar pattern with TK133 (published data of Tan et al., 2019) during the 2.65 to $1.67 \mathrm{kyr} \mathrm{BP}$ (Fig. 2). The uppermost TK40 $\delta^{18} \mathrm{O}$ values of $-6.03 \%$ at $8.840 \mathrm{kyr} B P$ match the lowermost $\delta^{18} \mathrm{O}$ values of TK20 between $8.840-8.878 \mathrm{kyr}$ BP (Fig. 2; Supplementary Data Table 1). These agreements indicate that TK7, TK20 and TK40 were most likely deposited under isotopic equilibrium and allow presenting the three records combined"'. (Lines 227-235)

E7. The manuscript lacks thorough discussion on the various mechanisms that affect Klang speleothem d180: ITCZ migration, monsoon signal, winter monsoons and tropical cyclones Indian summer monsoon and East Asian Monsoon. All these are mentioned in the text. It is important to add information on present-day local rainfall and cave drip water, and their d180?

Reply: We thank the editor for raising this important point. In this revised manuscript, we added information on present-day local rainfall and cave drip water and $\delta^{18} \mathrm{O}$ in Section 3.4 Cave drip water and rainwater monitoring; Result Section 4.2 Cave drip water and rainwater $\delta^{18} \mathrm{O}$; and Discussion Section 5.1 Climatic significance of $\delta^{18} \mathrm{O}$.

E8. Both reviewers give detailed comments that need to be addressed and if the authors wish to submit a corrected version, they have to explain how they modified the revised version according to the reviewers and the editor comments. The final decision regarding the manuscript will require further review.

Reply: We addressed all issues raised by both reviewers. The detailed point-to-point responses are given below. 


\section{$\underline{\text { Reviewers' Comments: }}$}

Reviewer \#1: The manuscript by Chawchai et al. presents a speleothem $\delta 180$ records spanning most of Holocene from Klang Cave in Thai-Malay Peninsula, southern Thailand. The major findings include disclosing a millennial drought period in the middle Holocene; identifying the 8.2-ka event in the tropical Indo-Pacific region and reconstructing the ITCZ shift index during the Holocene. The new record is no doubt important for us to understand the Holocene hydroclimate changes in tropical Indo-Pacific region.

Reply: We thank Reviewer \#1 for encouragement and constructive review.

However, there are several issues in data processing and interpreting need to be revised substantially.

Reply: We would like to thank Reviewer \#1 for the professional and constructive comments and suggestions. In the text below, we list all the reviewer' questions and comments, together with our responses highlighted in blue.

\section{Major comments:}

R1.1. Tan et al. (2019) have reported a speleothem $\delta 18 \mathrm{O}$ records from Klang cave and proposed the ITCZ shift index to understand shifts of ITCZ over the last 2700 years. From the paper by Tan et al., we know that there are substantial offsets of speleothem $\delta 18 \mathrm{O}$ among different stalagmites from Klang cave. By using normalized speleothem $\delta 18 \mathrm{O}$ data of single stalagmite to calculate the ITCZ index, these offsets can be ignored. However, by using different stalagmites which covering the different time periods, these offsets might lead to erroneous long-term trend. As seen from figure 4, stalagmite TK7 replicates well with TK20, but the replication between TK133 and TK7 is not so good, and there might be a offset of $0.5 \%$ between this two stalagmites (please using different colors to denote different stalagmites, the blue curve during the period from 2.5-1.6 kyr BP may mislead the reader that stalagmite TK20 overlapped with stalagmite TK133). Also, as there is no overlapping between TK40 and any other stalagmites, it's hard to evaluate how reliable the ITCZ index is in the early Holocene. Further evidences are necessary to confirm the present assessment.

Reply: (1) Considering the heterogeneous aquifer of different drips with the thickness of the overlying bedrock varying from 10 to $60 \mathrm{~m}$ above Klang Cave, the observed offsets could be attributed to different feeding systems for each stalagmite. Mixing of older and younger waters in the epikarst, and percolation along different flow paths can lead to buffering of the $\delta^{18} \mathrm{O}$ signal (Tan et al.,2019). Our observations in the cave show that drip water increases within hours of major rain events. Several intense rain events appear to have left distinct imprints in the cave drip water record with a lag of one week or two weeks. For example, the powerful storms that struck the peninsula around September $12^{\text {th }}$ and November $21^{\text {th }}$ could be recorded as distinct depletions in the cave drip water around September $28^{\text {th }}$ and November $25^{\text {th }}$, respectively (current manuscript Fig. 3). Therefore, cave drip water $\delta^{18} \mathrm{O}$ values generally reflect seasonal or yearly averages. In addition, similar patterns of $\delta^{18} \mathrm{O}$ variability between TK133 and TK7 support their suitability for tracking the original hydroclimate variability.

(2) The new figure 2 has been changed using different colors according to the comment and suggestion.

(3) Reviewer \#1 pointed out that "as there is no overlapping between TK40 and any other stalagmites, it's hard to evaluate how reliable the ITCZ index is in the early Holocene". Editor also raised this issue in E6. Please refer to our reply in E6. "A small gap is between TK20 and TK40 $\delta^{18} \mathrm{O}$ records (in the former manuscript). In the current manuscript, we did 
additional dating and isotopes analysis on the bottom of TK20 to fill this gap. The uppermost TK40 $\delta^{18} O$ values of $-6.03 \%$ at $8.840 \mathrm{kyr}$ BP match the lowermost $\delta^{18} O$ values of TK20 between $8.840-8.878 \mathrm{kyr}$ BP. These agreements show the fidelity of our reconstructed ITCZ SI record."

R1.2. I am confused about the position of the ITCZ at the southeast Asia. In the introduction, it is said that "over the Indian Ocean and adjoining land surfaces, the ITCZ shifts between $20^{\circ} \mathrm{N}$ in boreal summer and $8^{\circ} \mathrm{S}$ in boreal winter (Schneider et al., 2014). This shift was recorded over $25^{\circ} \mathrm{N}$ in the WPWP (e.g. Liu et al., 2015; Wang et al., 2008; Yancheva et al., 2007)." That means the ITCZ could shift to $20^{\circ} \mathrm{N}$ at least at present time.

Reply: Thank Reviewer \#1 for pointing out this mistake. The text was revised to "whereas over the Indian Ocean and adjoining land surfaces, the ITCZ shifts between $20^{\circ} \mathrm{N}$ in boreal summer and $8^{\circ} S$ in boreal winter during the observed period (Schneider et al., 2014). However, in paleorecords the ITCZ shifts reached over $25^{\circ} \mathrm{N}$ in the WPWP (e.g. Liu et al., 2015; Wang et al., 2008; Yancheva et al., 2007)." (Lines 97-99)

At line 271, it is said that "A possible explanation could be a quick southward shift of the ITCZ from $8^{\circ} \mathrm{N}$ or further north to closer to the equator during this millennium".

From figure 7, the ITCZ shift index record indicates that ITCZ was southward shift further during the last 2700 years than during the 6.0-5.2 kyr BP when the author suggest that the ITCZ was closer to the equator. It is to say that the ITCZ should be shift close to the equator at present. So, what position was indicated by the ITCZ index here?

Reply: To clarify this issue, the text was revised as "In contrast, the stalagmite $\delta^{18} \mathrm{O}$ records south of Klang Cave, such as Northern Borneo, Sumatra, Sulawesi, and Flores between $4^{\circ} \mathrm{N}-$ $\left.8^{\circ} \mathrm{S}\right)$, generally display opposite oscillations during the same period. Stalagmite $\delta^{18} \mathrm{O}$ data set from Flores shows a distinct anti-phase development to Klang $\delta^{18} \mathrm{O}$ record between 7.0 and $6.0 \mathrm{kyr}$ BP. The hydroclimate changes recorded in Klang Cave $\left(8^{\circ} \mathrm{N}\right)$ and in Secret Cave from Northern Borneo $\left(4^{\circ} \mathrm{N}\right)$ show opposite patterns during the early and middle Holocene, but a similar trend during the late Holocene. For the early and middle Holocene, Secret Cave and records from the southern Indo-Pacific region indicate wet conditions, which implies the climatic equator (mean position of the ITCZ) maintained between 4-8 ${ }^{\circ} \mathrm{N}$. The in-phase variations of the two records during the late Holocene indicate the climatic equator move further south of $4^{\circ} \mathrm{N}$ due to the declined northern hemisphere summer insolation." (Lines 353364)

R1.3. It is interesting that the $8.2 \mathrm{ka}$ event was identified in this tropical Indo-Pacific speleothem record. However, the event from $\sim 6.0$ to $5.4 \mathrm{kyr}$ BP is even more prominent than the 8.2-ka event. The authors mentioned that this event indicates a southward shift of ITCZ. But what drove this event, there is no any explanation. I think the explanation for this event is necessary.

Reply: This mid-Holocene event from $~ 6.0$ to $5.4 \mathrm{kyr}$ BP has been discussed in the revised manuscript on Lines 316-364. We wrote:

"The shift of stalagmite $\delta^{18} \mathrm{O}$ at $\sim 6.00 \mathrm{kyr} B P$ indicates a non-linear response to insolation forcing. To infer spatial patterns of the hydroclimate variability in the central Indo-Pacific region, Figure 4 shows a comparison of Klang Cave data set with speleothem records available in the Asian monsoon region, including (1) Dongge Cave, China (Wang et al., 2005; Dykoski et al., 2005), (2) Mawmluh Cave, India (Berkelhammer et al., 2013; Dutt et al., 2015), (3) Tham Doun Mai Cave, Laos (Griffiths et al., 2020), (4) Secret Cave, Northern Borneo (Carolin et al., 2013; Partin et al., 2007), (5) Tangga Cave, Sumatra (Wurtzel et al., 2018), (6) Gempa 
Bumi Cave, Sulawesi (Krause et al., 2019), and (7) Liang Luar Cave, Flores, Indonesia (Ayliffe et al., 2013; Griffiths et al., 2009) (see locations in Fig. 1).

The records between $25^{\circ} \mathrm{N}$ and the Indo-Pacific equatorial region indicate strong rainfall and strengthening of the Asian summer monsoon during the early Holocene, which follows the insolation curve for the wettest summer month (Fig. 4). Noticeable inconsistencies between records from $25^{\circ} \mathrm{N}-8^{\circ} \mathrm{N}$ and records from $4^{\circ} \mathrm{N}-8^{\circ} \mathrm{S}$ are, however; observed for the mid-Holocene. Klang Cave stalagmite $\delta^{18} \mathrm{O}$ values increase rapidly from 7.0 to $6.0 \mathrm{kyr} B P$, suggesting a shift towards relatively dry conditions in the northern central Indo-Pacific region. A comparable shift in speleothem $\delta^{18} \mathrm{O}$ can be found in Dongge Cave from 7.0 to $6.2 \mathrm{kyr} B P$ (Y. Wang et al., 2005) and from 5.8 to $5.2 \mathrm{kyr}$ BP (Dykoski et al., 2005), and in Mawmluh Cave at 7.0-6.5 kyr BP (Dutt et al., 2015) and 6.0-5.8 kyr BP (Berkelhammer et al., 2013). The sediment sequences of Lake Kumphawapi $\left(17^{\circ} \mathrm{N}\right.$; location in Fig. 1) in northeast Thailand also showed multiple hiatuses between 6.5 and $1.4 \mathrm{kyr} B P$, which are explained by periodic and severe dry time intervals affecting the wetland (Chawchai et al., 2016, 2013; Wohlfarth et al., 2016). A recent study of stalagmite $\delta^{18} \mathrm{O}$ from Laos indicated megadrought in Mainland Southeast Asia between 5 and 3 kyr BP (Griffiths et al., 2020), which could be the possible reason of the observed hiatus at 5.23-2.73 kyr BP in the Klang Cave record (Fig. 2 and 4).

Griffith et al (2020) suggested a major decrease of monsoon rainfall in Mainland Southeast Asia during the mid-to late Holocene, coincident with African monsoon failure during the end of the Green Sahara (Pausata et al., 2020; Shanahan et al., 2015; Tierney et al., 2017; Tierney and deMenocal, 2013). The drying of the Sahara reduced vegetation and increased dust loads shifted the Walker circulation eastward and cooled the Indian Ocean. Previous studies also suggested that warm SSTs in the eastern Pacific shifted the Walker circulation cell eastward, cooled and reduced atmospheric convergence in the eastern Indian Ocean (e.g. Abram et al., 2009; Berry and Reeder, 2013; Tian et al., 2017), causing a reduction in rainfall in the ISM regions during the mid-Holocene.

In contrast, the stalagmite $\delta^{18} \mathrm{O}$ records south of Klang Cave, such as Northern Borneo, Sumatra, Sulawesi, and Flores between $4^{\circ} \mathrm{N}-8^{\circ} \mathrm{S}$, generally display opposite oscillations during the same period. Stalagmite $\delta^{18} O$ data from Flores show a distinct anti-phase development to Klang $\delta^{18} \mathrm{O}$ record between 7.0 and $6.0 \mathrm{kyr}$ BP. The hydroclimate changes recorded in Klang Cave $\left(8^{\circ} \mathrm{N}\right)$ and in Secret Cave from Northern Borneo $\left(4^{\circ} \mathrm{N}\right)$ show opposite patterns during the early and middle Holocene, but a similar trend during the late Holocene. For the early and middle Holocene, Secret Cave and records from the southern Indo-Pacific region indicated wet conditions, which implies the climatic equator (mean position of the ITCZ) maintained a position between $4-8{ }^{\circ} \mathrm{N}$. The in-phase variations of the two records during the late Holocene indicate the climatic equator move further south of $4^{\circ} \mathrm{N}$ due to the declined northern hemisphere summer insolation."

Furthermore, in the ITCZ shift index record, the amplitude of 8.2-ka event is the same as other oscillations, and even smaller than that of some oscillations during the late Holocene. Why the $8.2-\mathrm{ka}$ event was not as prominent as in the $\delta 180$ record? Is there any other explanation for this?

Reply: Regarding for the small amplitude of $8.2 \mathrm{ka}$ in the derived ITCZ index, we believe that it is largely due to the bias caused by low resolution of the Liang Luar records. The ITCZ index is calculated from the subtraction between Klang Cave record and the Liang Luar record. Unfortunately, the Liang Luar record has lower resolution ( $\sim 50 \mathrm{yrs} /$ data point) from $\sim 6.2 \mathrm{ka}$ to $8.4 \mathrm{ka}$, and is particularly "zigzag" around $8.2 \mathrm{ka}$, largely due to low signal-noise ratio. 
While the ITCZ index is admittedly in low resolution around 6.2-8.4 ka, we want to emphasize that the index does capture the broad picture of how ITCZ moves during a major portion of the Holocene on millennial scale.

We added related discussion in Section 5.2 "However, the Liang Luar record has a lower resolution ( 50 yrs/data point) from 8.4 to $\sim 6.2 \mathrm{kyr} \mathrm{BP.} \mathrm{The} \mathrm{ITCZ} \mathrm{SI} \mathrm{can} \mathrm{only} \mathrm{reflect} \mathrm{millennial}$ to orbital changes during this time periods." (Lines 378-381).

R1.4. In the abstract, it is said that "Noticeable inconsistencies among records in the Southeast Asia region (between $8^{\circ} \mathrm{N}$ and $4^{\circ} \mathrm{N}-8^{\circ} \mathrm{S}$ ) have been documented on multi-centennial scales, likely resulting from the meridional shift of the intertropical convergence zone (ITCZ)." Why the meridional shift of the ITCZ could induce such inconsistence? Further explanation are necessary. Otherwise, it is a kind of baseless suspicion.

Reply: For two adjacent records, one $\delta^{18} \mathrm{O}$ record shifting positively and another one shifting negatively, it means the ITCZ mean position is moving from the first location to the second. We revised the text as "Noticeable inconsistencies among records in the Southeast Asia region (between $8^{\circ} \mathrm{N}$ and $4^{\circ} \mathrm{N}-8^{\circ} \mathrm{S}$ ) have been documented on multi-centennial scales. Lower $\delta^{18} \mathrm{O}$ values are likely associated with the mean position of the intertropical convergence zone (ITCZ).” (Lines 49-52)

\section{Other minor comments and suggestions}

R1.5. Line 38, A large increase of $2 \%$ in $\delta 180$ is observed from 7.0 to $6.0 \mathrm{kyr} \mathrm{BP}$, indicating a millennial drought period. Here the drought should be change to 'drying', the time period from 6.0 to 5.2 could be defined as a drought period.

Reply: The text was revised in Abstract according to the comment.

R1.6. Line 104-105, "Paleoclimatic records from the northern and southern regions of Southeast Asia document anti-phased rainfall responses to orbital processional insolation forcing." Please add the references for this sentence!

Reply: The reference was added.

R1.7. Line 121-122, the new record spans only most of early and middle Holocene and also a very short period in the late Holocene, but not the period from 11.259 to present. The description here should be precise.

Reply: Based on the comment, the text was revised as "Here, we present a new hydroclimate record of stalagmite $\delta^{18} \mathrm{O}$ from Klang Cave in southern Thailand $\left(8^{\circ} 20^{\prime} \mathrm{N}, 98^{\circ} 44^{\prime} \mathrm{E}\right.$; Fig. 1) from 11.23 to 5.23 thousand year (kyr BP, before 1950 AD) combined with the published record from the same cave of Tan et al. (2019) covering the Holocene.". (Lines 121-123).

R1.8. Please double check the stalage outputs, it is weird that the age-depth relationship twist in between two well-dated ages in the stalagmites TK40 and TK20.

Reply: We did test run the StalAge outputs several times (Supplementary Data Fig.2A). The twist in age model is a normal feature of StalAge (also confirmed by Prof. Denis Scholz developer of StalAge model). In addition, we also ran Bacon Age model (Supplementary Data Fig.2B).

"For stalagmite chronology, StalAge (Scholz and Hoffmann, 2011) and Bacon (Blaauw and Christen, 2011) give overlapping output results (Supplementary Data Fig. 2A, B). This consistency shows that the $U$-Th dated stalagmites ages are not sensitive to the choice of a 
specific age-depth model. Herein, we report the ages derived from the Bacon age model." This text has been added on Lines 215-219.

R1.9. In addition, it might be clear and informative to the reader if the author could indicate the dating layer and ages on the pictures of the stalagmite in figure 2 .

Reply: The dating layers have been indicated in the current Supplementary Data Figure 1.

R1.10. Line 250, Wang et al., 2005 should be added for the Dongge Cave, China. Reply: The reference was cited.

R1.11. Line 283-286, the formula [1] here is to normalize the record but not calculate the ITCZ shift index, it should be corrected.

Reply: The text was corrected accordingly.

R1.12. Line 304, "The north to south insolation differences decreased from $30 \mathrm{~W} / \mathrm{m} 2$ at 9.5 kyr BP to $0 \mathrm{~W} / \mathrm{m} 2$ at $6.0 \mathrm{kyr}$ BP." Which month(s) and at what latitudes? Please clarify!

Reply: The text was revised as "The insolation differences from north $\left(30^{\circ} \mathrm{N}\right)$ in June to south $\left(30^{\circ} \mathrm{S}\right)$ in December decreased from $30 \mathrm{~W} / \mathrm{m}^{2}$ at $9.5 \mathrm{kyr} \mathrm{BP}$ to $0 \mathrm{~W} / \mathrm{m}^{2}$ at $6.0 \mathrm{kyr} \mathrm{BP.",}$

Reviewer \#2: Chawchai et al. reported a follow-up study from Klang Cave, southern Thailand, after a recent publication by Tan et al. (2019, PNAS). The authors significantly extended the record, which now covers most of the last 11,000 years. The long record from Klang Cave shares a broad similarity with other speleothem-based monsoon records in East Asia and the western Pacific region. The record also presents its unique features, e.g., a dramatic $\mathrm{d} 18 \mathrm{O}$ positive shift at $\sim 6.0 \mathrm{kyr} \mathrm{BP}$, which the authors interpreted as a severe drought event. The authors continued the practice by Tan et al. (2019) and extended the ITCZ shift index. They concluded that the southward movement of the ITCZ since mid-Holocene can be tied to strengthening ENSO. I found the Klang speleothem data is of high quality, particularly in terms of U/Th dates, and ideas presented in the manuscript are also intriguing. I however have a few concerns and hope they can be addressed in the revision.

Reply: We would like to thank Reviewer \#2 for the positive statement and for the comments and suggestions to improve our manuscript.

R2.1. My major concern is that to what degree Klang speleothem $\mathrm{d} 18 \mathrm{O}$ can be quantified as a proxy of ITCZ migration. The raining season lasts from May to November in the region. While the rains in May and September are probably driven by the ITCZ, but hardly in other months when the ITCZ is located either far north or south. As the authors acknowledged, winter monsoons and tropical cyclones can also have significant contributions to the annual rainfall in the region. I would expect Chawchai et al. to have thorough discussions here. It seems that monitoring has been done at Klang. Any studies on local rainfall and cave drip water, in particular their $\mathrm{d} 18 \mathrm{O}$ ?

Reply: We thank this reviewer for raising this important point. In the revised manuscript, we added information on local rainfall and cave drip water, and their $\delta^{18} \mathrm{O}$ in different sections: Section 3.4 Cave drip water and rain water monitoring; Result Section 4.2 Cave drip water and rain water $\delta^{18} \mathrm{O}$; Discussion Section 5.1 Climatic significance of $\delta^{18} \mathrm{O}$. 
R2.2. Klang record resembles more closely East Asian monsoon records (e.g., Dongge records) rather than any other records from the tropical Indo-Pacific. This probably suggests that it is more appropriate to consider the record as a monsoon signal instead of ITCZ shift. The authors may argue that monsoon change and the ITCZ migration are in phase. If indeed so, the authors need to carefully elaborate their relationship, instead of arbitrarily lumping them together. Significant differences in fact exist between monsoon and the ITCZ, as the latter is mostly an oceanic feature. For example, figure 6 shows that ITCZ shift index monotonically decreases through the Holocene, also in the last 2,000 year as reported in Tan et al. (2019), but the Asian monsoon in fact becomes strengthened in the past 2,000 years (Cheng et al., 2016, Nature).

Reply: Thank Reviewer \#2 for giving this comment. Klang stalagmite $\delta^{18} \mathrm{O}$ record reflect regional rainfall variation. This cave is located in Asian monsoon realm. It is not surprising that Klang record is similar to stalagmite records from caves located in the same Asian monsoon realm. Klang record itself cannot reveal ITCZ history. Both Klang Cave, located in northern central Indo-Pacific (NCIP), and Liang Luar Cave, located in southern CIP (SCIP), were used to reconstructed ITCZ shift index record.

R2.3. The constructing of the ITCZ shift index is not without question. The early publication by Tan et al. (2019) has done a reasonably good job to argue that ITCZ latitudinal displacement is a dominant control in causing the difference of $\mathrm{d} 18 \mathrm{O}$ between Klang and Flores speleothems. But can we safely assume this control remains throughout the Holocene?

For example, Sunda Shelf flooding and sea surface temperature change in early-mid Holocene may have different impacts on climate over the two sites. The authors talked about ENSO and IOD in the manuscripts. Do they change rainfall and rainfall d18O similarly at Klang and Flores?

Figure 6 shows the two records are not mirror imaging. This suggests that one or both records recorded changes in addition to ITCZ displacement. A simple subtraction between the two $\mathrm{d} 18 \mathrm{O}$ records cannot remove these effects. It is ok to propose an index. However, once again, a careful discussion on the index, particularly caveats of the practice, would be helpful.

Reply: Thank this reviewer for pointing out this issue. Editor also raised this question. We discussed sea-level related Sunda Shelf exposure in the revised manuscript on Lines 426-434. We wrote: "Hydroclimate changes based on $\delta^{18} O$ record of Klang Cave in the western margin of WPWP are dominantly associated with the ISM (Tan et al., 2019). Substantial early to midHolocene decreases in the $\delta^{18} \mathrm{O}$ record of Liang Luar Cave are interpreted as an intensification of Australian-Indonesian summer monsoon rainfall in response to deglacial eustatic sea-level rise and flooding of the Sunda Shelf (Griffiths et al., 2009). This new regional ITCZ SI record (Fig. 7A) shows different trends than that of the Cariaco Basin Ti record from 11.0-7.0 kyr BP, especially around 11.0-9.5 kyr BP. This disagreement can likely be attributed to Sunda Shelf exposure due to sea level rise (Griffiths et al., 2009)."

R2.4. The writing in the manuscript can be significantly improved. For example, in the introduction, Chawchai et al. brought up several scientific questions to be addressed in the manuscript. These questions are all important and timely. I am however surprised that the authors didn't directly address them, at least not effectively in the following discussions. For example, the first paragraph talked about the timing of the onset and strengthening and weakening of the Asian monsoon, which is somewhat unpleasantly debated in the community. I however didn't see discussions on what the Klang record can contribute to this debate. Also, the 2nd paragraph talks about the difference between the Indian summer monsoon and East Asian monsoon. Great, but how does the difference relate to the Klang 
d180 interpretation? The connections are somehow missing through the text. Transitions are also needed between paragraphs.

Reply: Thank Reviewer \#2 for pointing out this. We agreed and rewritten the introduction Lines 70-86 as based on the current discussion.

\section{A few other comments and suggestions:}

R2.5. In highlights, not necessary to claim to be the "first" to report the 8.2-ka event in stalagmite records from the tropical Indo-Pacific. The authors might indeed be the first group. However, how exactly does this speleothem d180 shift relate to the 8.2-ka event in Greenland ice cores? It is probably more important to discuss why this event only occurred in southern Thailand, but not in other speleothem records in the region. Simply sample resolution issues, or chronology problems?

Reply: We agreed and lowered down the tune regarding the identification of $8.2 \mathrm{ka}$ event and remove the word "first" from the sentence in Highlights. "Stalagmite record of 8.2-ka event in the tropical Indo-Pacific region."

For the linkage between the $8.2 \mathrm{ka}$ event recorded in Greenland ice cores and the $\delta^{18} \mathrm{O}$ shift in our cave record, we have applied the well-accepted mechanism, i.e., through the weakening of AMOC and consequently the southward shift of the ITCZ (Lines 233-240 in the previous submission).

For clarity, the text has been changed to "It has been attributed to the last outburst flood from glacial Lake Agassiz, (Clarke et al., 2004; Lajeunesse and St-Onge, 2008; Teller et al., 2002), which freshened North Atlantic surface waters, reduced the production of North Atlantic Deep Water and weakened the North Atlantic Meridional Overturning Circulation (AMOC). A weakened AMOC hindered the northward transportation of warm surface waters, caused a southward shift of the ITCZ and reduced Asian monsoon (Cheng et al., 2009; Tan et al., 2020), and consequently a reduction of rainfall at our cave site, which led to a positive shift of $\delta^{18} \mathrm{O}$ in our stalagmite record." (Lines 295-303)

Regarding why 8.2-ka event has only been observed in southern Thailand, we propose that it can be largely attributed to low-resolution chronologies and sampling, and/or insensitive proxies in existing records. The clear forcing in this region could be related to several factors, e.g. the El Niño-Southern Oscillation, the Indian Ocean Dipole, and the movement of ITCZ. Due to this complexity, our current understanding of hydroclimate changes in this region is still limited. More regional records and simulations are required to address this issue in the future. (Lines 305-312)

R2.6. Lines 77-80, what are the exactly differences in the two monsoons? Differences can be caused by land-sea configurations.

Reply: To clarify this issue, we revised this part to "The Indian summer monsoon (ISM) and the East Asian summer monsoon (EASM), are the main components of the Asian monsoon system. Both interact with each other and are characterised by dissimilarities in the strengths and feedback mechanisms of the summer and winter monsoon regimes in the ISM and EASM regions caused by land-sea configurations, topography, and oceanic circulations (e.g. An et al., 2000; P. Wang et al., 2005; Wang et al., 2017; Y. Wang et al., 2005)." (Lines 74-80)

R2.7. Lines 87-88, what is "It" here?

Reply: The text was corrected from "It" to "The ITCZ". 
R2.8. Lines 92-93, it only affected the Atlantic ITCZ.

Reply: We agreed. The text was revised to "For the North Atlantic, observations during the $20^{\text {th }}$ century link the positions of the ITCZ to an interhemispheric heating imbalance driven by multi-decadal variability in the extratropical sea surface temperature (SST) (Green et al. 2017).” (Lines 88-91)

R2.9. Lines $187-188$. This is likely a wrong statement. Hendy test is to test whether calcite/aragonite precipitates under equilibrium conditions. This test is no longer helpful. Replication test is more robust one.

Reply: The text was revised to "Hendy tests (Hendy, 1971) were performed on five laminae of the three stalagmites (Supplementary Data Fig. 3) and duplication tests (Dorale and Liu, 2009) were done to decipher whether the speleothems were subject to the same conditions during their growth." (Lines 188-191)

R2.10. Lines 202-203, need to reword.

Reply: The text was revised as " $\delta{ }^{18} O$ variations of TK7 replicate TK20 during $8.35-7.34 \mathrm{kyr}$ BP and show similar pattern with TK133 (published data of Tan et al., 2019) during the 2.65 to 1.67 kyr BP (Fig. 2)" (Lines 229-231)

R2.11. Lines 301, which "insolation"? Annual, JJA, or daily? Figure 7 needs to be marked clearly accordingly.

Reply: The text was revised as "Summer insolation over the northern extratropics $\left(30^{\circ} \mathrm{N}\right)$ in June was much stronger between 12.0 and $9.5 \mathrm{kyr}$ BP as compared to the southern extratropics $\left(30^{\circ} S\right)$ in December." and marked in Figure 6 in the revised manuscript.

R2.12. Figures

The quality of figures needs to be improved. QSR does not have a strict limitation in publication pages. However, some figures, if not much informative, are better to be deposited in supplementary materials.

For example, it is great that authors show stalagmite photos in Figure 2. However, the images are in rather poor quality. They need to be replaced by better images, so readers can see crystal structures more clearly. Better to move them to supplementary materials. Also helpful to mark a few U/Th dates on sample images.

Reply: The quality of Figure 2 was improved and this figure was moved to Supplementary Data Figure 1. Layers for U-Th dating were marked in the figure images.

R2.13. Figure 3 can be moved to supplementary.

Reply: Figure 3 was moved to Supplementary Data Figure 2A.

R2.14. Figure 4, A and B better also be moved to supplementary. Figure $4 \mathrm{C}$ however can be substantially improved, e.g., using different colors for different specimens. U/Th date symbols can be color coded as well.

Reply: Figure 4 A and B were moved to Supplementary Data Figure 3. Figure 4C has been improved in the revised manuscript as new Figure 2.

R2.15. Figure 5 also can be improved. I personally don't enjoy reading many curves in one figure. Figures need to have clean presentation, can convey a clear message.

Reply: This figure was improved as the new Figure 3 in the new manuscript. 
R2.16. Table $1 .{ }^{238} \mathrm{U}$ and ${ }^{232} \mathrm{Th}$ concentrations should be in ppb and ppt, respectively. Also, "\%" unit for $\mathrm{d} 234 \mathrm{U}$ measured and corrected initial values.

Reply: The text in Table $1{ }^{238} \mathrm{U}$ and ${ }^{232} \mathrm{Th}$ concentrations has been changed to ppb and ppt, respectively, and unit \%o has been added to $\delta^{234} \mathrm{U}$. 


\section{Highlights}

- Holocene stalagmite $\delta^{18} \mathrm{O}$ record of Thai-Malay Peninsula, southern Thailand.

- Wet conditions/strong rainfall during 11-7 kyr BP and a drying trend since $6 \mathrm{kyr}$ BP.

- Stalagmite record of 8.2-ka event in the tropical Indo-Pacific region.

- A new Holocene ITCZ shift index record for the central Indo-Pacific region. 
Hydroclimate variability of central Indo-Pacific region during the

Holocene

3 Sakonvan Chawchai ${ }^{1 *}$, Liangcheng Tan $^{2,3,4}$, Ludvig Löwemark ${ }^{5}$, Hao-Cheng Wang ${ }^{5,6,7}$,

4 Tsai-Luen $\mathrm{Yu}^{5,6,8}$, Yun-Chuan Chung ${ }^{5,6,7}$, Horng-Sheng Mii ${ }^{9}$, Guangxin Liu $^{10}$, Maarten

5 Blaauw ${ }^{11}$, Shou-Yeh Gong ${ }^{12}$, Barbara Wohlfarth ${ }^{13}$, Chuan-Chou Shen ${ }^{5,6,7 *}$

6

7

${ }^{1}$ Morphology of Earth Surface and Advanced Geohazards in Southeast Asia Research Unit (MESA), Department of Geology, The Faculty of Science, Chulalongkorn University, Bangkok 10330, Thailand

${ }^{2}$ State Key Laboratory of Loess and Quaternary Geology, Institute of Earth Environment, Chinese Academy of Sciences, Xi'an 710075, China

${ }^{3}$ Center for Excellence in Quaternary Science and Global Change, Chinese Academy of Sciences, Xi'an 710061, China

${ }^{4}$ Institute of Global Environmental Change, Xi'an Jiaotong University, 710049 Xi'an, China

${ }^{5}$ Department of Geosciences, National Taiwan University, Taipei 10617, Taiwan, ROC

${ }^{6}$ High-precision Mass Spectrometry and Environment Change Laboratory (HISPEC), Department of Geosciences, National Taiwan University, Taipei 10617, Taiwan, ROC ${ }^{7}$ Research Center for Future Earth, National Taiwan University, Taipei 10617, Taiwan, ROC ${ }^{8}$ Marine Industry and Engineering Research Center, National Academy of Marine Research, Kaohsiung City 80661, Taiwan, ROC

${ }^{9}$ Department of Earth Sciences, National Taiwan Normal University, Taipei 10617, Taiwan, $R O C$

${ }^{10}$ Research Center for Earth System Science, Yunnan University, Kunming 650500, China ${ }^{11}$ Archaeology and Palaeoecology, School of Natural and Built Environment, Queen's University Belfast, Belfast BT7 1NN, United Kingdom

${ }^{12}$ Department of Geology, National Museum of Natural Science, Taichung 40419, Taiwan, $R O C$

${ }^{13}$ Department of Geological Sciences, Stockholm University and Bolin Centre for Climate Research, Stockholm University, 10691 Stockholm, Sweden

*To whom correspondence should be addressed:

Assistant Prof. Dr. Sakonvan Chawchai: Tel: 669-61611187;

E-mail: sakonvan.c@chula.ac.th

Prof. Dr. Chuan-Chou Shen: Tel: 886-2-33665878; Fax: 886-2-33651917;

E-mail: river@ntu.edu.tw 

9

\section{Abstract}

Here we present a decadal-resolved hydroclimate record covering the past 11 thousand years based on $\delta^{18} \mathrm{O}$ data of three stalagmites from Klang Cave (TK) on the Thai-Malay Peninsula, southern Thailand. The $\delta^{18} \mathrm{O}$ values indicate wetter conditions/more rainfall during the early Holocene from 11 to 7 thousand years before present (kyr BP). A large increase of $2 \%$ in $\delta^{18} \mathrm{O}$ is observed from 7.0 to $6.0 \mathrm{kyr} \mathrm{BP}$, indicating a millennial drying period followed by drought conditions between 6.0 and $5.2 \mathrm{kyr}$ BP. After a long hiatus (5.2-2.7 kyr BP), $\delta^{18} \mathrm{O}$ data show a millennium-long trend toward dry conditions. An abrupt positive change of $0.8-1.0 \%$ in $\delta^{18} \mathrm{O}$ is noticed between $8.29-8.17 \mathrm{kyr} \mathrm{BP}$, reflecting the 8.2-ka event, however; the amplitude of the $\delta^{18} \mathrm{O}$ shift is much smaller when compared to 6.0-5.2 kyr BP. On orbital time-scales, the TK record agrees with insolation-dominated speleothem records in the Asian-Australian monsoon realm. Noticeable inconsistencies among records in the Southeast Asia region (between $8^{\circ} \mathrm{N}$ and $4^{\circ} \mathrm{N}-8^{\circ} \mathrm{S}$ ) have been documented on multi-centennial scales. Lower $\delta^{18} \mathrm{O}$ values are likely associated with the mean position of the Intertropical Convergence Zone (ITCZ). A new reconstruction of Holocene ITCZ shifts index within the central IndoPacific region, based on stalagmite $\delta^{18} \mathrm{O}$ records from Klang Cave $\left(8^{\circ} \mathrm{N}\right)$ and Liang Luar Cave $\left(8^{\circ} \mathrm{S}\right)$, shows that the ITCZ played an important role in hydroclimate variability in the Asian-Australian monsoon regions. The southward shift of the ITCZ in the central Indo-Pacific region, controlled by the interhemispheric extratropical 7 insolation gradient, may strongly correlate with the El Niño-Southern Oscillation (ENSO) activities in the Holocene.

Keywords: Stalagmite; Thai-Malay Peninsula; Holocene; ITCZ; central Indo-Pacific region 


\section{Highlights}

$64 \cdot$ Holocene stalagmite $\delta^{18} \mathrm{O}$ record of Thai-Malay Peninsula, southern Thailand.

65 - Wet conditions/strong rainfall during 11-7 kyr BP and a drying trend since 6 kyr BP.

66 - Stalagmite record of 8.2-ka event in the tropical Indo-Pacific region.

67 - A new Holocene ITCZ shift index record for the central Indo-Pacific region. 


\section{Introduction}

Numerous geological and biological records, including loess, lake sediments, peat and stalagmites, showed that the strength of the Asian summer monsoon during the Holocene followed insolation patterns, with an increased summer monsoon intensity during the early Holocene and a gradual decline from the mid-Holocene onwards (e.g. Kutzbach, 1981; P. Wang et al., 2005; Y. Wang et al., 2005). The Indian summer monsoon (ISM) and the East Asian summer monsoon (EASM) are the main components of the Asian monsoon system. Both interact with each other and are characterised by dissimilarities in the strengths and feedback mechanisms of the summer and winter monsoon regimes in the ISM and EASM regions, caused by landsea configurations, topography, and oceanic circulations (e.g. An et al., 2000; Li et al., 2019; P. Wang et al., 2005; Wang et al., 2017; Y. Wang et al., 2005). The boundary between the ISM and EASM regions is generally set at around $105^{\circ} \mathrm{E}$ (Wang et al., 2003; P. Wang et al., 2005). A further component of the monsoon system is the Intertropical Convergence Zone (ITCZ), which refers to the monsoon trough and trade wind convergence zone and corresponds to the location of maximum persistent rainfall. The ITCZ plays an important role for hydroclimate variability in the Asian monsoon regions (Chao and Chen, 2001; Clift and Plumb, 2008; Gadgil, 2018; Wang, 2009).

Nowadays, a significant annual displacement (summer/winter) of the ITCZ can be observed over the Indian Ocean and the western Pacific Warm Pool (WPWP). For the North Atlantic, observations during the $20^{\text {th }}$ century link the positions of the ITCZ to an interhemispheric heating imbalance driven by multi-decadal variability in the extratropical sea surface temperature (SST) (Green et al. 2017). For Asia, several studies suggested that the position and expansion of the ITCZ over land in the Asian monsoon region are inter-related with monsoon rains and that its mean northward extent is influenced by the strength in summer monsoon (Chiang and Friedman, 2012; Dallmeyer et al., 2013; Fleitmann et al., 2007; Schneider et al., 2014; Yancheva et al., 2007). Over the Pacific Ocean, the ITCZ migrates between $9^{\circ} \mathrm{N}$ in boreal summer and $2^{\circ} \mathrm{N}$ in boreal winter, whereas over the Indian Ocean and adjoining land surfaces, the ITCZ shifts between $20^{\circ} \mathrm{N}$ in boreal summer and $8^{\circ} \mathrm{S}$ in boreal winter during the observed period (Schneider et al., 2014). However, in paleorecords the ITCZ shifts reached over $25^{\circ} \mathrm{N}$ in the WPWP (e.g. Liu et al., 2015; Wang et al., 2008; Yancheva et 
101 al., 2007). Annual changes in the migration of the ITCZ therefore strongly affect the

102

103

104

105

106

107

108

109

110

111

112

113

114

115

116

117

118

119

120

121

122

123

124

125

126

127

128

129

130

131

132

133

regional hydroclimate in large parts of Southeast Asia.

Paleoclimatic records from the northern and southern regions of Southeast Asia document anti-phased rainfall responses to orbital processional insolation forcing (Griffiths et al., 2020, 2009; Krause et al., 2019; Tan et al., 2019; Wu et al., 2020). Millennial-scale climate events detected by various proxies have been interpreted as latitudinal shifts of the ITCZ during the last deglaciation and the Holocene (e.g. Ayliffe et al., 2013; Chawchai et al., 2013; Denniston et al., 2013; Tan et al., 2019; Tierney et al., 2010; Wurtzel et al., 2018). However, the spatial distribution of paleoclimatic records used for most of these studies are from north of $25^{\circ} \mathrm{N}$ and from the Indo-Pacific equatorial region, with few records between $5-20^{\circ} \mathrm{N}$ in the ISM dominated tropics.

The Thai-Malay Peninsula is located between the Indian and Indo-Pacific climate systems. Recently, Tan et al. (2019) suggested that rainfall variations during the last 2,700 years were in-phase between Thai-Malay Peninsula and southern Indo-Pacific region on centennial-to decadal time scales, despite their anti-phase variations on orbital- to suborbital-scales. These results highlight the ITCZ's influence on regional precipitation changes, despite of the impact of the El Niño-Southern Oscillation (ENSO). A better knowledge of how climate varied in the past in this region could thus enhance insight into the interactions between ISM and the western Indo-Pacific Warm Pool (IPWP) over longer timescales.

Here, we present a new hydroclimate record of stalagmite $\delta^{18} \mathrm{O}$ from Klang Cave in southern Thailand ( $8^{\circ} 20^{\prime} \mathrm{N}, 98^{\circ} 44^{\prime}$ E; Fig. 1) from 11.23 to 5.23 thousand year (kyr BP, before $1950 \mathrm{AD}$ ) combined with the published record from the same cave of Tan et al. (2019) covering the Holocene. This site fills an important gap in the spatial distribution of tropical paleoclimatic records north of the present-day mean position of the ITCZ $\left(\sim 3^{\circ} \mathrm{N}\right)$, and could further develop our understanding of hydroclimate changes, regional differences, and the dynamics in tropical/subtropical Asian monsoon areas.

\section{Regional settings}

Klang Cave $\left(8^{\circ} 1^{\prime} \mathrm{N}, 98^{\circ} 48^{\prime} \mathrm{E}\right)$ is located in the Ao-Luek District, Krabi Province, Thai-Malay Peninsula, southern Thailand (Fig. 1A \& C). The regional tower karst developed in the massive Permian limestone and dolomitic limestone of the Ratburi Group (Department of Mineral Resources, 2013). The present-day climate in the region 
134 is characterized by the ISM, the northeast winter monsoon, the ITCZ, and by tropical

135 cyclones from the South China Sea (Thai Meteorological Department, 2017). ISM

136 rainfall occurs during the rainy season, mostly from May to October. The first arrival

137 of the ITCZ to southern Thailand is usually in May. Afterward it moves northwards and

138 is situated across southern China from around June to early July. The ITCZ then moves

139 south again and is located over southern Thailand in September and October. The

140 northeast winter monsoon generally causes abundant regional rainfall in November.

141 The east coast of Thai Peninsula receives additional moisture during the winter

142 monsoon. However, the Khao Luang Mountain Range situated in the middle part of the

143 Peninsula blocks moist air from reaching the west coast where Klang Cave is situated.

144 Tropical cyclones occur occasionally in October and November. The National

145 Oceanic and Atmospheric Administration's Hybrid Single Particle Langarian

146 Integrated Trajectory (HYSPLIT) model ensembles depict air-parcel/moisture transport

147 routes, highlighting the contrast between summer monsoon (May-October) and winter

148 monsoon (November-April) seasons (Tan et al., 2019). Mean annual temperatures in

149 Krabi range from $26.5^{\circ} \mathrm{C}$ in winter to $28.5^{\circ} \mathrm{C}$ in summer and annual precipitation

150 amounts to 2,000-2,800 mm (2010-2018 AD) (Fig. 1B).

151

152

153

154

155

156

157

158

159

160

161

162

163

164

165

\section{Materials and methods}

\subsection{Cave setting and stalagmite sampling}

Our first survey of Klang Cave (1100-m-long main passageway) was conducted in 2010. Cave air temperature data were recorded from April 2011 to August 2012 by six temperature loggers, Maxim DS1921H High-Resolution Thermochron®iButton, installed at locations $100-300 \mathrm{~m}$ from the cave entrance. The inner part of the cave, 50 $\mathrm{m}$ from the entrance, is well enclosed with $>95 \%$ humidity and a steady cave temperature of $23{ }^{\circ} \mathrm{C}$. The consistency of the temperature records between the six measuring sites indicates a uniform thermal condition in the cave system (Tan et al., 2019). Three broken aragonite stalagmites, TK7, TK20, and TK40 (90-140 cm in length, 4-10 cm in diameter), were collected in 2010 in a chamber $400 \mathrm{~m}$ from the cave entrance (Supplementary Data Fig. 1).

\subsection{Chronology}


166

167

168

169

170

171

172

173

174

175

176

177

178

179

180

181

182

183

184

185

186

187

188

189

190

191

192

193

194

195

196

197

198

The three stalagmites were cut into halves along their growth axes and polished. Xray diffraction (XRD) analysis at 6 depths (Supplementary data Fig. 1) show that all stalagmites are composed of pure aragonite without mineral transformation. A total of 33 layers, 19, 8 and 6 layers for TK7, TK20 and TK40, respectively, were drilled for U-Th dating (Table 1). U and Th contents and isotopic compositions were analyzed using a multi-collector inductively coupled mass spectrometer, Thermo NEPTUNE, at the High Precision Mass Spectrometry and Environment Change Laboratory (HISPEC), National Taiwan University (NTU)(Shen et al., 2012). The half-lives of the nuclides used for age calculations are given in Cheng et al. (2013). Uncertainties in isotopic data and ${ }^{230} \mathrm{Th}$ dates, relative to $1950 \mathrm{AD}$, are given at the two-sigma $(2 \sigma)$ level or two standard deviations of the mean $\left(2 \sigma_{\mathrm{m}}\right)$. Both Monte Carlo approach simulated age models StalAge (Scholz and Hoffmann, 2011) and Bacon (Blaauw and Christen, 2011) were used to evaluate the chronology for each stalagmite.

\subsection{Stable Isotope Analysis}

For $\delta^{18} \mathrm{O}$ isotopic analysis, subsamples were drilled with a hand-held driller from the central axis at 3-mm resolution for TK7 and TK20 and at 10-mm resolution for TK40. Oxygen isotopic $\left(\delta^{18} \mathrm{O}\right)$ profiles were measured on 701 subsamples on a Thermo MAT 253 isotope ratio mass spectrometer (IRMS) at the Department of Geosciences, NTU, and a Micromass IsoPrime IRMS at the Department of Earth Science, National Taiwan Normal University (NTNU). $\delta^{18} \mathrm{O}$ values are reported in per mil (\%o), relative to the Vienna PeeDee Belemnite (VPDB) (Supplementary Data Table 1) and standardization was accomplished using NBS-19 $\left(\delta^{18} \mathrm{O}=-2.20 \%\right)$. Hendy tests (Hendy, 1971) were performed on five laminae of the three stalagmites (Supplementary Data Fig. 3) and duplication tests (Dorale and Liu, 2009) were done to decipher whether the speleothems were subject to the same conditions during their growth.

\subsection{Cave drip water and rain water monitoring}

Cave drip water samples were collected daily from active stalactites in the deeper chambers of the Klang Cave system from two periods covering parts of the summer monsoon season during August $16^{\text {th }}$ to September $30^{\text {th }}$, and parts of the winter monsoon season during October $1^{\text {st }}$ to December $31^{\text {st }}$ in 2013. Rain water samples were collected daily for the same period at the meteorological station at Krabi Airport, 
199 Thailand. For $\delta \mathrm{D}$ and $\delta^{18} \mathrm{O}$ analysis, water samples were collected in 100-ml plastic 200 bottles and tightly sealed to prevent any isotopic alterations due to evaporation. Both 201 cave drip water and rain water samples were analysed in a Picarro L2130-i Isotopic $202 \mathrm{H}_{2} \mathrm{O}$ Analyzer at the Institute of Earth Sciences, Academia Sinica, in Taiwan. The 203 analytical details were following the method for cavity ring-down spectroscopy (Brand 204 et al., 2009; Laskar et al., 2014). $\delta \mathrm{D}$ and $\delta^{18} \mathrm{O}$ values are expressed as \%o in relative to 205 VSMOW. The precisions of the measurements, evaluated on standards, were better than $2061 \%$ for $\delta \mathrm{D}$ and $0.1 \%$ for $\delta^{18} \mathrm{O}$.

\section{Results}

\subsection{Chronology and Stalagmite $\delta^{18} O$}

U-Th isotopic data and ages are listed in Table 1. Stalagmites show high uranium contents of up to $16 \mathrm{ppm}$ and low thorium values as low as $21 \mathrm{ppt}$, which allows for precise U-Th dating with an age uncertainty of $\pm 6-43$ years. All dates are in

213 stratigraphic order. Two U-Th ages of $2758 \pm 20$ and $5255 \pm 37 \mathrm{yr}$ BP at depths of 18 214 and $28 \mathrm{~mm}$ of stalagmite TK7 indicate that a dark layer at $21 \mathrm{~mm}$ is a hiatus 215 (Supplementary Data Fig. 1). For stalagmite chronology, StalAge (Scholz and 216 Hoffmann, 2011) and Bacon (Blaauw and Christen, 2011) give overlapping output results (Supplementary Data Fig. 2A, B). This consistency shows that the U-Th dated stalagmites ages are not sensitive to the choice of a specific age-depth model. Herein, we report the ages derived from the Bacon age model. Within $95 \%$ certainty of the age model, stalagmite TK7 grew between $8.35-1.67$ kyr BP with a likely hiatus from 5.23-

2212.73 kyr BP. Stalagmites TK20 and TK40 are dated to 8.88-7.34 and 11.23-8.84 kyr 222 BP, respectively. The high growth rates of $0.3-0.5 \mathrm{~mm} / \mathrm{yr}$ for TK7, TK20 and TK40 223 allow the reconstruction of decadal-scale stable isotope records between 11.23 and 5.23 kyr BP (Fig. 2).

The Hendy Test (Hendy, 1971) shows similar coeval $\delta^{18} \mathrm{O}$ values with small variations of $\pm 0.02-0.08 \%$ for all three stalagmites from the centre to the rim of the same layer (Supplementary Data Fig. 3A, B). Systematic offsets between stalagmite

$228 \delta^{18} \mathrm{O}$ records in Klang Cave were reported in Tan et al. (2019). Similar oxygen isotopic 229 discrepancies are not noticeable in this study. $\delta^{18} \mathrm{O}$ variations of TK7 replicate TK20 230 during 8.35-7.34 kyr BP and show similar pattern with TK133 (published data of Tan 231 et al., 2019) during the 2.65 to $1.67 \mathrm{kyr}$ BP (Fig. 2). The uppermost TK40 $\delta^{18} \mathrm{O}$ values 
of $-6.03 \%$ at $8.840 \mathrm{kyr}$ BP match the lowermost $\delta^{18} \mathrm{O}$ values of TK20 between 8.840 8.878 kyr BP (Fig. 2; Supplementary Data Table 1). These agreements indicate that TK7, TK20 and TK40 were most likely deposited under isotopic equilibrium and allow presenting the three records combined.

The combined Holocene TK $\delta^{18} \mathrm{O}$ values range from -7.09 to $-4.04 \%$ (Fig. 2). $\delta^{18} \mathrm{O}$ values of TK40 gradually decreased from $-5 \%$ at $11.23 \mathrm{kyr}$ BP to $-7 \%$ at $10.0 \mathrm{kyr}$ BP. Between 10.0 and $7.0 \mathrm{kyr} \mathrm{BP}, \delta^{18} \mathrm{O}$ values range from -7.0 to $-5.4 \%$, but notably relatively high $\delta^{18} \mathrm{O}$ values of $\sim-5.7 \%$ is observed between 8.3 and $8.2 \mathrm{kyr}$ BP.

The composite $\delta^{18} \mathrm{O}$ record in Figure 2 exhibits large changes of $\sim 2 \%$ from 7.0 to 6.0 kyr BP and remain higher than the mean value between 6.0-5.2 kyr BP. Also, color changes are observed in stalagmite petrography during this time period (Supplementary Data Fig. 1). After the hiatus between 5.2 and $2.7 \mathrm{kyr}$ BP, a millennium-long trend to high $\delta^{18} \mathrm{O}$ values of -2.7 to $-3.5 \%$ is recorded in TK133 (Tan et al., 2019).

\subsection{Cave drip water and rain water $\delta^{18} \mathrm{O}$}

The $\delta^{18} \mathrm{O}$ values of cave drip water for the first period (August-September), roughly corresponding to the latter part of the summer monsoon, display relatively small variability from -7.5 to $-3.6 \%$ with an average of $-5.5 \%$, while the second period (October-December) displays larger variability with values from -6.6 to $-0.8 \%$ and an average of $-4.4 \%$ (Fig. 3A). The observed isotopic averages of cave drip water are close to the amount weighted $\delta^{18} \mathrm{O}$ of precipitation of the entire study period $(-5.4 \%$ ) (Fig. 3B), but do not show any direct relationship to the amount of weighted monthly variations in $\delta^{18} \mathrm{O}$ in precipitation. The isotopic composition of the cave drip water also falls close to the global meteoric water line (GMWL) (Fig. 3C).

\section{Discussion}

\subsection{Climatic significance of $\delta^{18} \mathrm{O}$}

The close agreement between drip water $\delta^{18} \mathrm{O}$ at Klang Cave and amountweighted $\delta^{18} \mathrm{O}$ precipitation suggests that the water recharging the aquifer that feeds the cave is hardly influenced by evaporative processes. While the residence time of the ground water in the aquifer above the cave is unknown, observations in the cave show that drip water increases within hours of major rain events. In particular, several intense 
264 rain events appear to have left distinct imprints in the cave drip water record with a lag 265 of one to two weeks. For example, the powerful storms that struck the peninsula on 266 September $12^{\text {th }}$ and November $21^{\text {st }} 2013$ seem to have been recorded as distinct 267 depletions in the cave drip water around September $28^{\text {th }}$ and November $25^{\text {th }}$, 268 respectively (Fig. 3). Therefore, we assume that Klang Cave drip water $\delta^{18} \mathrm{O}$ values 269 generally reflect seasonal or yearly averages precipitation $\delta^{18} \mathrm{O}$.

270 Negative correlations between monthly rainfall amount and precipitation $\delta^{18} \mathrm{O}(\mathrm{r}=$ $271-0.64, \mathrm{P}<0.01$ ), as well as between the amount of annual rainfall and weighted mean 272 precipitation $\delta^{18} \mathrm{O}(\mathrm{r}=-0.58, \mathrm{P}<0.01)$, are observed at the Bangkok GNIP station, the 273 longest Global Network of Isotopes in Precipitation station (GNIP) in Thailand 274 (http://www-naweb.iaea.org/napc/ih/IHS_resources_gnip.html). In addition, the recent 275 study of isotopic composition of precipitation across Thailand during 2013-2015 276 showed that the lower values of $\delta^{18} \mathrm{O}$ in southern Thailand during December-February 277 and March-May are attributable to the precipitation amount effect dominated by 278 oceanic moisture (Laonamsai et al, 2020). Tan et al. (2019) suggested that local 279 precipitation, as well as the convection and rainfall upstream of Klang Cave could affect 280 the precipitation/stalagmite $\delta^{18} \mathrm{O}$ in this region. As a result, we followed Tan et al. (2019) 281 to interpret the new stalagmite $\delta^{18} \mathrm{O}$ record from Klang Cave as reflecting the rainfall 282 variations in the northern central Indo-Pacific region, with a negative $\delta^{18} \mathrm{O}$ shift representing high amounts of rainfall, and vice versa.

\subsection{Holocene rainfall variations and regional comparisons}

During the early Holocene, from $11.2-10.0 \mathrm{kyr}$ BP, the combined TK $\delta^{18} \mathrm{O}$ data set shows a general trend towards relatively wetter conditions. The record features a millennial-scale trend towards drier conditions, punctuated by an abrupt enrichment of $0.8-1.0 \%$ in $\delta^{18} \mathrm{O}$ between 8.3 and $8.2 \mathrm{kyr} \mathrm{BP}$, which could be an expression of the 8.2ka event (Cheng et al., 2009; Dixit et al., 2014). Increasing $\delta^{18} \mathrm{O}$ values between 7.0 and $5.2 \mathrm{kyr}$ BP reflect overall drying conditions. The increase of $\sim 1.5 \%$ in $\delta^{18} \mathrm{O}$ is particularly abrupt and prominent at $6.0 \mathrm{kyr}$ BP.

294 (Rohling and Pälike, 2005; Thomas et al., 2007) and in many paleorecords from across 295 the globe (e.g. Morrill and Jacobsen, 2005; Jin et al., 2007). It has been attributed to the 296 last outburst flood from glacial Lake Agassiz (Clarke et al., 2004; Lajeunesse and St- 
Onge, 2008; Teller et al., 2002), which freshened North Atlantic surface waters, reduced the production of North Atlantic Deep Water and weakened the North Atlantic Meridional Overturning Circulation (AMOC). A weakened AMOC hindered the northward transportation of warm surface waters, caused a southward shift of the ITCZ and reduced Asian monsoon (Cheng et al., 2009; Tan et al., 2020), and consequently a reduction of rainfall at our cave site, which led to a positive shift of $\delta^{18} \mathrm{O}$ in our stalagmite record.

The impact of the 8.2-ka event has however remained elusive in the tropical IndoPacific region (Chabangborn et al., 2020). Regarding why 8.2-ka event has only been observed in southern Thailand, we propose that it can be largely attributed to lowresolution chronologies and sampling, and/or insensitive proxies in existing records. The clear forcing in this region could be related to several factors, e.g. the El NiñoSouthern Oscillation, the Indian Ocean Dipole, and the movement of ITCZ. Due to this complexity, our current understanding of hydroclimate changes in this region is still limited. More regional records and simulations are required to address this issue in the future. Our record clearly identifies the 8.2-ka event and provides evidence that teleconnections between abrupt climate shifts in the North Atlantic and tropical Indo-

314 Pacific climate existed not only during glacial periods (Cheng et al., 2009; Chiang and 315 Friedman, 2012; Gupta et al., 2003), but also during the Holocene.

316 The shift of stalagmite $\delta^{18} \mathrm{O}$ at $\sim 6.00 \mathrm{kyr}$ BP indicates a non-linear response to 317 insolation forcing. To infer spatial patterns of the hydroclimate variability in the central 318 Indo-Pacific region, Figure 4 shows a comparison of Klang Cave data set with 319 speleothem records available in the Asian monsoon region, including (1) Dongge Cave, 320 China (Wang et al., 2005; Dykoski et al., 2005), (2) Mawmluh Cave, India 321 (Berkelhammer et al., 2013; Dutt et al., 2015), (3) Tham Doun Mai Cave, Laos 322 (Griffiths et al., 2020), (4) Secret Cave, Northern Borneo (Carolin et al., 2013; Partin 323 et al., 2007), (5) Tangga Cave, Sumatra (Wurtzel et al., 2018), (6) Gempa Bumi Cave, 324 Sulawesi (Krause et al., 2019), and (7) Liang Luar Cave, Flores, Indonesia (Ayliffe et al., 2013; Griffiths et al., 2009) (see locations in Fig. 1).

The records between $25^{\circ} \mathrm{N}$ and the Indo-Pacific equatorial region indicate strong rainfall and strengthening of the Asian summer monsoon during the early Holocene,

328 which follows the insolation curve for the wettest summer month (Fig. 4). Noticeable 329 inconsistencies between records from $25^{\circ} \mathrm{N}-8^{\circ} \mathrm{N}$ and records from $4^{\circ} \mathrm{N}-8^{\circ} \mathrm{S}$ are, 330 however; observed for the mid-Holocene. Klang Cave stalagmite $\delta^{18} \mathrm{O}$ values increase 
331 rapidly from 7.0 to $6.0 \mathrm{kyr} \mathrm{BP}$, suggesting a shift towards relatively dry conditions in 332 the northern central Indo-Pacific region. A comparable shift in speleothem $\delta^{18} \mathrm{O}$ can be 333 found in Dongge Cave from 7.0 to $6.2 \mathrm{kyr}$ BP (Y. Wang et al., 2005) and from 5.8 to 3345.2 kyr BP (Dykoski et al., 2005), and in Mawmluh Cave at 7.0-6.5 kyr BP (Dutt et al., 335 2015) and 6.0-5.8 kyr BP (Berkelhammer et al., 2013). The sediment sequences of 336 Lake Kumphawapi $\left(17^{\circ} \mathrm{N}\right.$; location in Fig. 1) in northeast Thailand also showed 337 multiple hiatuses between 6.5 and $1.4 \mathrm{kyr} \mathrm{BP}$, which are explained by periodic and 338 severe dry time intervals affecting the wetland (Chawchai et al., 2016, 2013; Wohlfarth 339 et al., 2016). A recent study of stalagmite $\delta^{18} \mathrm{O}$ from Laos indicated megadrought in 340 Mainland Southeast Asia between 5 and 3 kyr BP (Griffiths et al., 2020), which could 341 be the possible reason of the observed hiatus at 5.23-2.73 kyr BP in the Klang Cave 342 record (Fig. 2 and 4).

343 Griffith et al (2020) suggested a major decrease of monsoon rainfall in Mainland 344 Southeast Asia during the mid- to late Holocene, coincident with African monsoon 345 failure during the end of the Green Sahara (Pausata et al., 2020; Shanahan et al., 2015; 346 Tierney et al., 2017; Tierney and deMenocal, 2013). The drying of the Sahara reduced 347 vegetation and increased dust loads shifted the Walker circulation eastward and cooled 348 the Indian Ocean. Previous studies also suggested that warm SSTs in the eastern Pacific 349 shifted the Walker circulation cell eastward, cooled and reduced atmospheric 350 convergence in the eastern Indian Ocean (e.g. Abram et al., 2009; Berry and Reeder, 351 2013; Tian et al., 2017), causing a reduction in rainfall in the ISM regions during the 352 mid-Holocene.

353 In contrast, the stalagmite $\delta^{18} \mathrm{O}$ records south of Klang Cave, such as Northern 354 Borneo, Sumatra, Sulawesi, and Flores between $4^{\circ} \mathrm{N}-8^{\circ} \mathrm{S}$, generally display opposite 355 oscillations during the same period. Stalagmite $\delta^{18} \mathrm{O}$ data from Flores show a distinct 356 anti-phase development to Klang $\delta^{18} \mathrm{O}$ record between 7.0 and $6.0 \mathrm{kyr}$ BP. The 357 hydroclimate changes recorded in Klang Cave $\left(8^{\circ} \mathrm{N}\right)$ and in Secret Cave from Northern 358 Borneo $\left(4^{\circ} \mathrm{N}\right)$ show opposite patterns during the early and middle Holocene, but a 359 similar trend during the late Holocene. For the early and middle Holocene, Secret Cave 360 and records from the southern Indo-Pacific region indicated wet conditions, which 361 implies the climatic equator (mean position of the ITCZ) maintained a position between $3624-8{ }^{\circ} \mathrm{N}$. The in-phase variations of the two records during the late Holocene indicate 
363 the climatic equator move further south of $4^{\circ} \mathrm{N}$ due to the declined northern hemisphere summer insolation.

\subsection{A new record of Holocene ITCZ shift index for the central Indo-Pacific region}

Over the Holocene, sea level and topography have not been the main factors controlling the hydroclimate change. Instead, insolation appears to be the most important forcing to drive shifts in the position of ITCZ (Tan et al., 2019, and references therein). We used the formula [1] in Tan et al. (2019) to normalize the Klang Cave $\delta^{18} \mathrm{O}$ record (TK) at $8^{\circ} \mathrm{N}$ and the stalagmite $\delta^{18} \mathrm{O}$ record (LL) of Liang Luar Cave from $8^{\circ} \mathrm{S}$.

$$
\mathrm{x}^{*}=\left(\mathrm{x}-\mathrm{x}_{\min }\right) /\left(\mathrm{x}_{\max }-\mathrm{x}_{\min }\right),
$$

374 where $\mathrm{x}$ is the original $\delta^{18} \mathrm{O}$ value, $\mathrm{x}_{\max }$ and $\mathrm{x}_{\min }$ are the maximum and minimum values 375 of the time series, respectively, and $\mathrm{x} *$ is the normalized data. The ITCZ shift index 376 (SI) was constructed by subtracting the LL record (Fig. 5D) from the TK record (Fig. 5B) (with a 10-yr moving average of normalized data based on different age uncertainties and proxy resolutions). However, the Liang Luar record has a lower resolution ( $\sim 50 \mathrm{yrs} /$ data point) from 8.4 to $\sim 6.2 \mathrm{kyr}$ BP. The ITCZ SI can only reflect millennial to orbital changes during this time periods. The calculated ITCZ SI record is plotted in Figure 5E.

Relative negative (positive) ITCZ SI values represent more (less) rainfall in the northern central Indo-Pacific as compared to the southern central Indo-Pacific, indicating a northward (southward) shift of the central Indo-Pacific ITCZ during the Holocene (Fig. 5E). The newly reconstructed ITCZ SI record shows that the mean position of the ITCZ in the central Indo-Pacific region maintained its northernmost position between 11.3 and $9.5 \mathrm{kyr}$ BP. Thereafter, it continuously shifted to the south, with centennial- to decadal-fluctuations toward present day (Fig. 5E). The orbital-scale change of the ITCZ in the central Indo-Pacific during the Holocene follows the

390 insolation differences between the extratropical northern and southern hemispheres

391 (Fig. 6A, C), supporting the atmospheric energy balance of the ITCZ mechanism 392 (Schneider et al., 2014). Summer insolation over the northern extratropics $\left(30^{\circ} \mathrm{N}\right)$ in 393 June was much stronger between 12.0 and $9.5 \mathrm{kyr} \mathrm{BP}$ as compared to the southern 394 extratropics $\left(30^{\circ} \mathrm{S}\right)$ in December. This led to a persistent northward cross-equatorial energy flux, resulting in the northernmost ITCZ mean positions in the central Indo- 
396 Pacific region. The insolation differences from north $\left(30^{\circ} \mathrm{N}\right)$ in June to south $\left(30^{\circ} \mathrm{S}\right)$ in

397 December decreased from $30 \mathrm{~W} / \mathrm{m}^{2}$ at $9.5 \mathrm{kyr} \mathrm{BP}$ to $0 \mathrm{~W} / \mathrm{m}^{2}$ at $6.0 \mathrm{kyr} \mathrm{BP}$. After that, 398 insolation in the southern extratropics began exceeding that in the northern part (Fig. 399 6C), which led to the southward shift of the ITCZ (Fig. 6A).

400 The orbital-scale southward shift of the ITCZ in the central Indo-Pacific region 401 corresponds to enhanced ENSO activities in the Pacific (Moy et al., 2002) since the 402 mid-Holocene (Fig. 6A, D). Both proxy data and model studies have shown an increase 403 in ENSO activities during the mid-Holocene (6-5 kyr BP) (Clement et al., 2000; 404 Donders et al., 2008; Liu et al., 2000) and a shift toward a more El Niño-like climate 405 state (Chiang et al., 2009; Emile-Geay et al., 2016; Koutavas and Joanides, 2012). 406 Similar conditions - a southward mean position of the ITCZ and enhanced El Niño 407 conditions - are also observed for the last 2 thousand years, i.e. that during the early 408 Medieval Warm Period and the Current Warm Period (Tan et al., 2019). During the 409 strong El Niño events of 1983 and 1998 AD, the ITCZ in the Indo-Pacific also moved 410 to the south (Liu et al., 2012).

411 Our ITCZ SI record is generally consistent with the ITCZ shift in the tropical 412 Atlantic reconstructed using the Ti content in marine sediments from the Cariaco Basin $413\left(10^{\circ} \mathrm{N}, 65^{\circ} \mathrm{W}\right)$ (Fig. 6A, B) (Haug et al., 2001). Both records show a long-term 414 southward movement of the mean ITCZ position during the Holocene, which points to 415 coherent variations of ITCZ in the central Indo-Pacific and in the tropical Atlantic. 416 However, discrepancies existed during the early Holocene. The ITCZ in the tropical 417 Atlantic shifted to the north since the beginning of the Holocene to $9.5 \mathrm{kyr}$ BP (its 418 northernmost position) and moved southward thereafter (Fig. 6B). We speculate that 419 the out-of-phase response of the ITCZ in the tropical Atlantic to the insolation was 420 caused by the relative cold sea surface temperature at $12-10 \mathrm{kyr}$ BP in the north Atlantic. 421 Reconstructions reveal an increasing SST in the north Atlantic during the early 422 Holocene (Fig. 6E) (Bard et al., 2000; Jiang et al., 2015). This may explain the increased 423 energy export to the north Atlantic, resulting in a northward shift of the ITCZ in tropical 424 Atlantic region (Schneider et al., 2014). However, on millennial time scales, the 425 dynamics of the eastern equatorial Pacific may differ from the western equatorial 426 Pacific (Trenberth and Stepaniak, 2001). Hydroclimate changes based on $\delta^{18} \mathrm{O}$ record 427 of Klang Cave in the western margin of WPWP are dominantly associated with the ISM 428 (Tan et al., 2019). Substantial early to mid-Holocene decreases in the $\delta^{18} \mathrm{O}$ record of 429 Liang Luar Cave are interpreted as an intensification of Australian-Indonesian summer 
430 monsoon rainfall in response to deglacial eustatic sea-level rise and flooding of the

431 Sunda Shelf (Griffiths et al., 2009). This new regional ITCZ SI record (Fig. 7A) shows

432 different trends than that of the Cariaco Basin Ti record from 11.0-7.0 kyr BP,

433 especially around 11.0-9.5 kyr BP. This disagreement can likely be attributed to Sunda

434 Shelf exposure due to sea level rise (Griffiths et al., 2009).

435

6. Conclusions

A new composite stalagmite $\delta^{18} \mathrm{O}$ record from Klang Cave, southern Thailand, allows reconstructing regional Holocene hydroclimate variability. Klang Cave $\delta^{18} \mathrm{O}$ values are consistent with the characteristic speleothem records from the Asian monsoon domain and show an increasing trend throughout the Holocene, which is related to the decline of northern hemisphere summer insolation, indicating decreasing rainfall in the northern central Indo-Pacific region. The new stalagmite $\delta^{18} \mathrm{O}$ data set reveals stronger rainfall between 11.23-7.00 kyr BP; dry conditions between 8.3-8.2 and between 7.0-5.2 kyr BP, and a multi-centennial scale trend toward drier conditions for the last $2.7 \mathrm{kyr}$ BP. The 8.2-ka event could be clearly identified in the tropical IndoPacific region, indicating a teleconnection of abrupt climate shifts with the North Atlantic region. The reconstructed Holocene ITCZ shift index suggests that the mean location of the ITCZ in the central Indo-Pacific region maintained its northernmost position between 11.2 and $9.5 \mathrm{kyr} \mathrm{BP}$, but moved to the south of $4^{\circ} \mathrm{N}$ during the late Holocene. The ITCZ variations in the central Indo-Pacific are generally consistent with those in the tropical Atlantic, except for the early Holocene period. Although ENSO may have influenced tropical rainfall dynamics after the mid-Holocene, the effects of ITCZ/insolation forcing, and ENSO are difficult to disentangle.

\section{Credits authorship contribution statement}

456 C-C.S. and B.W. supervised the project and provided resources. S.C. wrote the original 457 draft and made all figures with help from L.T., C-C.S. and B.W. S.C., L.L. and C-C.S. 458 investigated and conducted a field survey and sampling. S.C. and H-C.W. performed 459 sample preparation and Hendy Test. H-C.W., T-L.Y., Y.-C.C. and H-S.M. did U-Th 460 dating and isotope analysis. G.L., M.B. and S-Y.G contributed some ideas and helped 461 to improve the manuscript. All authors discussed the results, reviewed and edited the manuscript. 
463

464

465

466

467

468

469

470

471

472

473

474

475

476

477

478

479

480

481

482

483

484

485

486

487

488

489

490

491

492

493

494

\section{4}

\section{Declaration of Competing Interest}

The authors declare that they have no known competing financial interests or personal relationships that could have appeared to influence the work reported in this paper.

\section{Acknowledgements}

We are thankful for the financial support provided by the DPST Research grant 042/2558 (S.C.), grants from the Science Vanguard Research Program of the Ministry of Science and Technology (MOST) (108-2119-M-002-012, 109-2123-M-002-001 to C.-C.S.), the National Taiwan University (109L8926 to C.-C.S.), the Higher Education Sprout Project of the Ministry of Education, Taiwan ROC (109L901001 to C.-C.S.). L.L. acknowledges financial support from Ministry of Science and Technology (MOST grant 106-2116-M-002 -021). L.T. would like to thank the supported from the Strategic Priority Research Program of Chinese Academy of Sciences (XDB40000000). B.W. acknowledges support through Swedish Research Council (VR) research grants 6212008-2855, 621-2011-4684 and 348-2008-6071. We deeply appreciate Assistant Prof. Dr. Akkaneewut Chabangborn for his help and devotion during cave survey, and Prof. Dr. Chakkaphan Sutthirat and Montri Choowong for logical support and mentorship. We also thank officials at Ao-Luek, Krabi province, Sak's Family, Tasnai (White) Sukkeewan, Manatthawut (Nong) ChuSaeng for their hospitality in the field and beautiful photographs, and Dr. Raphael Bissen for proofreading the draft.

\section{Figure captions}

Figure 1: (A) Locations of Klang Cave (red star) and other sites: (1) Dongge Cave, China $\left[25^{\circ} \mathrm{N}, 108^{\circ} \mathrm{E}\right]$ (Dykoski et al., 2005; Y. Wang et al., 2005), (2) Mawmluh Cave, India [25 $\left.{ }^{\circ}, 9^{\circ} \mathrm{E}\right]$ (Berkelhammer et al., 2013; Dutt et al., 2015), (3) Tham Doun Mai Cave, Laos $\left[20^{\circ} \mathrm{N}, 102^{\circ} \mathrm{E}\right]$ (Griffiths et al., 2020), (4) Secret Cave, Northern Borneo [4으, $\left.114^{\circ} \mathrm{E}\right]$ (Carolin et al., 2013; Partin et al., 2007), (5) Tangga Cave, Sumatra $\left[0^{\circ} 21^{\prime} \mathrm{S}, 100^{\circ} \mathrm{E}\right]$ (Wurtzel et al., 2018), (6) Gempa Bumi Cave, Sulawesi [5 $\left.{ }^{\circ} \mathrm{S}, 120^{\circ} \mathrm{E}\right]$ (Krause et al., 2019) and (7) Liang Luar Cave, Flores, Indonesia [ $\left.8^{\circ} \mathrm{S}, 120^{\circ} \mathrm{E}\right]$ (Ayliffe et al., 2013; Griffiths et al., 2009), and lake sediment (8) Lake Kumphawapi [17º N, $\left.102^{\circ} \mathrm{E}\right]$ (Chawchai et al., 2016, 2013; Wohlfarth et al., 2016). (B) Mean monthly rainfall 
and temperatures (2010-2018 AD) for Krabi airport station, situated $45 \mathrm{~km}$ SE of Klang Cave. (C) A chamber with speleothem $50 \mathrm{~m}$ from the entrance of Klang Cave.

Figure 2: Integrated $\delta^{18} \mathrm{O}$ records of TK7, TK20 and TK40 (this study), and of TK133 (Tan et al., 2019). U-Th ages and errors are color-coded by stalagmite.

Figure 3: (A) Cave drip water $\delta^{18} \mathrm{O}$ during August-December 2013. (B) Rainwater $\delta^{18} \mathrm{O}$ during August-December 2013 and (C) Stable isotope composition of drip water compared to Global Meteoric Water Line (GMWL). Inset map shows simplified outline of Klang Cave and the position of the drip water sampling station. Blue bars in (B) indicate weighted monthly average $\delta^{18} \mathrm{O}$.

Figure 4: Comparison of stalagmite $\delta^{18} \mathrm{O}$ records between Klang Cave and (A) Dongge Cave, China (Dykoski et al., 2005; Y. Wang et al., 2005); (B) Mawmluh Cave, India (Berkelhammer et al., 2013; Dutt et al., 2015); (C) Tham Doun Mai Cave, Laos (Griffiths et al., 2020); (D) Klang Cave (This study); (E) Secret Cave, Northern Borneo (Carolin et al., 2013; Partin et al., 2007); (F) Tangga Cave, Sumatra (Wurtzel et al., 2018); (G) Gempa Bumi Cave, Sulawesi (Krause et al., 2019) and (H) Liang Luar Cave, Flores, Indonesia (Ayliffe et al., 2013; Griffiths et al., 2009). See also location in Figure $1 \mathrm{~A}$.

Figure 5: Reconstruction of the ITCZ Shift Index (SI) for the Holocene. (A) Composite TK $\delta^{18} \mathrm{O}$ record. (B) Normalized annual TK $\delta^{18} \mathrm{O}$ record. (C) Original $\delta^{18} \mathrm{O}$ record Liang Luar Cave (LL) from Flores, Indonesia (Ayliffe et al., 2013; Griffiths et al., 2009). (D) Normalized annual LL $\delta^{18} \mathrm{O}$ record. Black lines in $\mathbf{B}$ and $\mathbf{D}$ are 10 -yr moving averages of the normalized TK and LL records, respectively. (E) The reconstructed ITCZ SI series (green line) results from subtracting the smoothed LL dataset from the TK record.

Figure 6: Comparison of (A) the reconstructed ITCZ SI series in the central IndoPacific region (this study) with (B) Ti content of the marine sediments in the Cariaco Basin (Haug et al., 2001), (C) Summer insolation differences between $30^{\circ} \mathrm{N}$ in June and $30^{\circ} \mathrm{S}$ in December (Berger and Loutre, 1991), (D) ENSO frequency in the pacific 
528 reconstructed from Laguna Pallcacocha (Moy et al., 2002), and (E) North Atlantic (NA)

529 SST reconstructed from Iberian margin core SU8118 (Bard et al., 2000).

\section{Table captions}

532 Table 1: Stalagmite U-Th dating results.

534 Supplementary Data Table 1: Time series TK7, TK20 and TK40 $\delta^{18} \mathrm{O}$ record for this 535 study and TK133 (Tan et al., 2019) and The ITCZ shift index (SI).

Supplementary Data Figure 1: Polished quartered/halved sections of stalagmites

538 TK7, TK20, and TK40. Six brown layers represent the depths for X-ray diffraction 539 analysis (XRD). Red horizons are layers for U-Th dating and determined ages are given 540 by layers. Blue lines are the subsampling routes for oxygen isotope analysis. A dashed 541 line at $2.1 \mathrm{~mm}$ of TK7 denotes a hiatus.

543 Supplementary Data Figure 2A: StalAge age models for TK7, TK20, and TK40.

544 Black square shapes show the U-Th dates with errors. Green lines indicate the StalAge 545 model. Red lines are the $95 \%$ confidence ranges.

547 Supplementary Data Figure 2B: Bacon age models for TK7, TK20, and TK40. The 548 blue shapes show the dates with two standard deviations, the green line indicates the 549 likely age model, and the red lines show the $95 \%$ confidence ranges of the age models.

551 Supplementary Data Figure 3: Hendy Test on coeval subsamples of (A) TK07, and 552 (B) TK20 and TK40.

\section{References}

Abram, N.J., McGregor, H.V., Gagan, M.K., Hantoro, W.S., Suwargadi, B.W., 2009. Oscillations in the southern extent of the Indo-Pacific Warm Pool during the mid-Holocene - ScienceDirect. Quat. Sci. Rev. 28, 2794-2803. https://doi.org/10.1016/j.quascirev.2009.07.006

An, Z., Porter, S.C., Kutzbach, J.E., Xihao, W., Suming, W., Xiaodong, L., Xiaoqiang, L., Weijian, Z., 2000. Asynchronous Holocene optimum of the East Asian monsoon. Quat. Sci. Rev. 19, 743-762. https://doi.org/10.1016/S0277-3791(99)00031-1

Ayliffe, L.K., Gagan, M.K., Zhao, J., Drysdale, R.N., Hellstrom, J.C., Hantoro, W.S., Griffiths, M.L., Scott-Gagan, H., Pierre, E.S., Cowley, J.A., Suwargadi, B.W., 
2013. Rapid interhemispheric climate links via the Australasian monsoon during the last deglaciation. Nat. Commun. 4, 2908. https://doi.org/10.1038/ncomms3908

Bard, E., Rostek, F., Turon, J.-L., Gendreau, S., 2000. Hydrological Impact of Heinrich Events in the Subtropical Northeast Atlantic. Science 289, 13211324. https://doi.org/10.1126/science.289.5483.1321

Berger, A., Loutre, M.-F., 1991. Insolation values for the climate of the last 10 million years. Quat. Sci. Rev. 10, 297-317.

Berkelhammer, M., Sinha, A., Stott, L., Cheng, H., Pausata, F.S.R., Yoshimura, K., 2013. An abrupt shift in the Indian monsoon 4000 years ago, in: Climates, Landscapes, and Civilizations. American Geophysical Union (AGU), pp. 7588. https://doi.org/10.1029/2012GM001207

Berry, G., Reeder, M.J., 2013. Objective identification of the intertropical convergence zone: Climatology and trends from the ERA-Interim. J. Clim. 27, 1894-1909. https://doi.org/10.1175/JCLI-D-13-00339.1

Blaauw, M., Christen, J.A., 2011. Flexible paleoclimate age-depth models using an autoregressive gamma process. Bayesian Anal. 6, 457-474. https://doi.org/10.1214/11-BA618

Brand, W.A., Geilmann, H., Crosson, E.R., Rella, C.W., 2009. Cavity ring-down spectroscopy versus high-temperature conversion isotope ratio massspectrometry; a case study on delta $\delta^{2} \mathrm{H}$ and $\delta^{18} \mathrm{O}$ of pure water samples and alcohol/water mixtures. Rapid Commun. Mass Spectrom. RCM 23, 18791884. https://doi.org/10.1002/rcm.4083

Carolin, S.A., Cobb, K.M., Adkins, J.F., Clark, B., Conroy, J.L., Lejau, S., Malang, J., Tuen, A.A., 2013. Varied response of western Pacific hydrology to climate forcings over the last glacial period. Science 340, 1564-1566. https://doi.org/10.1126/science.1233797

Chabangborn, A., Punwong, P., Phountong, K., Nudnara, W., Yoojam, N., Sainakum, A., Won-In, K., Sompongchaiyakul, P., 2020. Environmental changes on the west coast of the Gulf of Thailand during the 8.2 ka event. Quat. Int. 536, 103-113. https://doi.org/10.1016/j.quaint.2019.12.020

Chao, W.C., Chen, B., 2001. The origin of monsoons. J. Atmospheric Sci. 58, 34973507. https://doi.org/10.1175/1520-0469(2001)058<3497:TOOM>2.0.CO;2

Chawchai, S., Chabangborn, A., Kylander, M., Löwemark, L., Mörth, C.-M., Blaauw, M., Klubseang, W., Reimer, P.J., Fritz, S.C., Wohlfarth, B., 2013. Lake Kumphawapi - An archive of Holocene palaeoenvirontal and palaeoclimatic changes in northeast Thailand. Quat. Sci. Rev. 68, 59-75. https://doi.org/10.1016/j.quascirev.2013.01.030

Chawchai, S., Yamoah, K.A., Smittenberg, R.H., Kurkela, J., Väliranta, M., Chabangborn, A., Blaauw, M., Fritz, S.C., Reimer, P.J., Wohlfarth, B., 2016. Lake Kumphawapi revisited - The complex climatic and environmental record of a tropical wetland in NE Thailand. The Holocene 26, 614-626. https://doi.org/10.1177/0959683615612565

Cheng, H., Fleitmann, D., Edwards, R.L., Wang, X., Cruz, F.W., Auler, A.S., Mangini, A., Wang, Y., Kong, X., Burns, S.J., Matter, A., 2009. Timing and structure of the $8.2 \mathrm{kyr}$ B.P. event inferred from $\delta^{18} \mathrm{O}$ records of stalagmites from China, Oman, and Brazil. Geology 37, 1007-1010. https://doi.org/10.1130/G30126A.1

Cheng, H., Lawrence Edwards, R., Shen, C.-C., Polyak, V.J., Asmerom, Y., Woodhead, J., Hellstrom, J., Wang, Y., Kong, X., Spötl, C., Wang, X., Calvin 
Alexander Jr., E., 2013. Improvements in ${ }^{230} \mathrm{Th}$ dating, ${ }^{230} \mathrm{Th}$ and ${ }^{234} \mathrm{U}$ half-life values, and U-Th isotopic measurements by multi-collector inductively coupled plasma mass spectrometry. Earth Planet. Sci. Lett. 371-372, 82-91. https://doi.org/10.1016/j.eps1.2013.04.006

Chiang, J.C.H., Fang, Y., Chang, P., 2009. Pacific climate change and ENSO activity in the mid-Holocene. J. Clim. 22, 923-939. https://doi.org/10.1175/2008JCLI2644.1

Chiang, J.C.H., Friedman, A.R., 2012. Extratropical cooling, interhemispheric thermal gradients, and tropical climate change. Annu. Rev. Earth Planet. Sci. 40, 383-412. https://doi.org/10.1146/annurev-earth-042711-105545

Clarke, G.K.C., Leverington, D.W., Teller, J.T., Dyke, A.S., 2004. Paleohydraulics of the last outburst flood from glacial Lake Agassiz and the 8200 BP cold event. Quat. Sci. Rev. 23, 389-407. https://doi.org/10.1016/j.quascirev.2003.06.004

Clement, A.C., Seager, R., Cane, M.A., 2000. Suppression of El Niño during the midHolocene by changes in the Earth's orbit. Paleoceanography 15, 731-737. https://doi.org/10.1029/1999PA000466

Clift, P.D., Plumb, R.A., 2008. The Asian Monsoon: Causes, History and Effects. Cambridge University Press, Cambridge.

Dallmeyer, A., Claussen, M., Wang, Y., Herzschuh, U., 2013. Spatial variability of Holocene changes in the annual precipitation pattern: a model-data synthesis for the Asian monsoon region. Clim. Dyn. 40, 2919-2936. https://doi.org/10.1007/s00382-012-1550-6

Denniston, R.F., Wyrwoll, K.-H., Polyak, V.J., Brown, J.R., Asmerom, Y., Wanamaker, A.D., LaPointe, Z., Ellerbroek, R., Barthelmes, M., Cleary, D., Cugley, J., Woods, D., Humphreys, W.F., 2013. A stalagmite record of Holocene Indonesian-Australian summer monsoon variability from the Australian tropics. Quat. Sci. Rev. 78, 155-168. https://doi.org/10.1016/j.quascirev.2013.08.004

Department of Mineral Resources, 2013. Geological Map of Changwat Krabi, Scale 1: 250,000 .

Dixit, Y., Hodell, D.A., Sinha, R., Petrie, C.A., 2014. Abrupt weakening of the Indian summer monsoon at 8.2 kyr B.P. Earth Planet. Sci. Lett. 391, 16-23. https://doi.org/10.1016/j.epsl.2014.01.026

Donders, T.H., Wagner-Cremer, F., Visscher, H., 2008. Integration of proxy data and model scenarios for the mid-Holocene onset of modern ENSO variability. Quat. Sci. Rev. 27, 571-579. https://doi.org/10.1016/j.quascirev.2007.11.010

Dorale, J.A., Liu, Z., 2009. Limitations of Hendy test criteria in judging the paleoclimatic suitability of speleothems and the need for replication. J. Cave Karst Stud. 71, 73-80.

Dutt, S., Gupta, A.K., Clemens, S.C., Cheng, H., Singh, R.K., Kathayat, G., Edwards, R.L., 2015. Abrupt changes in Indian summer monsoon strength during 33,800 to 5500 years B.P. Geophys. Res. Lett. 42, 5526-5532. https://doi.org/10.1002/2015GL064015

Dykoski, C.A., Edwards, R.L., Cheng, H., Yuan, D., Cai, Y., Zhang, M., Lin, Y., Qing, J., An, Z., Revenaugh, J., 2005. A high-resolution, absolute-dated Holocene and deglacial Asian monsoon record from Dongge Cave, China. Earth Planet. Sci. Lett. 233, 71-86. https://doi.org/10.1016/j.epsl.2005.01.036

Emile-Geay, J., Cobb, K.M., Carré, M., Braconnot, P., Leloup, J., Zhou, Y., Harrison, S.P., Corrège, T., McGregor, H.V., Collins, M., Driscoll, R., Elliot, M., Schneider, B., Tudhope, A., 2016. Links between tropical Pacific seasonal, 
interannual and orbital variability during the Holocene. Nat. Geosci. 9, 168173. https://doi.org/10.1038/ngeo2608

Fleitmann, D., Burns, S.J., Mangini, A., Mudelsee, M., Kramers, J., Villa, I., Neff, U., Al-Subbary, A.A., Buettner, A., Hippler, D., Matter, A., 2007. Holocene ITCZ and Indian monsoon dynamics recorded in stalagmites from Oman and Yemen (Socotra). Quat. Sci. Rev. 26, 170-188. https://doi.org/10.1016/j.quascirev.2006.04.012

Gadgil, S., 2018. The monsoon system: Land-sea breeze or the ITCZ? J. Earth Syst. Sci. 127, 1. https://doi.org/10.1007/s12040-017-0916-x

Griffiths, M.L., Drysdale, R.N., Gagan, M.K., Zhao, J. -x, Ayliffe, L.K., Hellstrom, J.C., Hantoro, W.S., Frisia, S., Feng, Y. -x, Cartwright, I., Pierre, E.S., Fischer, M.J., Suwargadi, B.W., 2009. Increasing Australian-Indonesian monsoon rainfall linked to early Holocene sea-level rise. Nat. Geosci. 2, 636639. https://doi.org/10.1038/ngeo605

Griffiths, M.L., Johnson, K.R., Pausata, F.S.R., White, J.C., Henderson, G.M., Wood, C.T., Yang, H., Ersek, V., Conrad, C., Sekhon, N., 2020. End of Green Sahara amplified mid- to late Holocene megadroughts in mainland Southeast Asia. Nat. Commun. 11, 4204. https://doi.org/10.1038/s41467-020-17927-6

Gupta, A.K., Anderson, D.M., Overpeck, J.T., 2003. Abrupt changes in the Asian southwest monsoon during the Holocene and their links to the North Atlantic Ocean. Nature 421, 354-357. https://doi.org/10.1038/nature01340

Haug, G.H., Hughen, K.A., Sigman, D.M., Peterson, L.C., Röhl, U., 2001. Southward migration of the intertropical convergence zone through the Holocene. Science 293, 1304-1308. https://doi.org/10.1126/science.1059725

Hendy, C.H., 1971. The isotopic geochemistry of speleothems-I. The calculation of the effects of different modes of formation on the isotopic composition of speleothems and their applicability as palaeoclimatic indicators. Geochim. Cosmochim. Acta 35, 801-824. https://doi.org/10.1016/0016-7037(71)90127$\mathrm{X}$

Hiess, J., Condon, D.J., McLean, N., Noble, S.R., 2012. ${ }^{238} \mathrm{U} /{ }^{235} \mathrm{U}$ systematics in terrestrial uranium-bearing minerals. Science 335, 1610-1614. https://doi.org/10.1126/science.1215507

Jaffey, A.H., Flynn, K.F., Glendenin, L.E., Bentley, W.C., Essling, A.M., 1971. Precision measurement of half-lives and specific activities of ${ }^{235} \mathrm{U}$ and ${ }^{238} \mathrm{U}$. Phys. Rev. C 4, 1889-1906. https://doi.org/10.1103/PhysRevC.4.1889

Jiang, H., Muscheler, R., Björck, S., Seidenkrantz, M.-S., Olsen, J., Sha, L., Sjolte, J., Eiríksson, J., Ran, L., Knudsen, K.-L., Knudsen, M.F., 2015. Solar forcing of Holocene summer sea-surface temperatures in the northern North Atlantic. Geology 43, 203-206. https://doi.org/10.1130/G36377.1

Jin, Z., Yu, J., Chen, H., Wu, Y., Wang, S., Chen, S., 2007. The influence and chronological uncertainties of the 8.2 ka cooling event on continental climate records in China. The Holocene 17, 1041-1050. https://doi.org/10.1177/0959683607082439

Koutavas, A., Joanides, S., 2012. El Niño-Southern Oscillation extrema in the Holocene and Last Glacial Maximum. Paleoceanography 27. https://doi.org/10.1029/2012PA002378

Krause, C.E., Gagan, M.K., Dunbar, G.B., Hantoro, W.S., Hellstrom, J.C., Cheng, H., Edwards, R.L., Suwargadi, B.W., Abram, N.J., Rifai, H., 2019. Spatiotemporal evolution of Australasian monsoon hydroclimate over the last 40,000 
years. Earth Planet. Sci. Lett. 513, 103-112. https://doi.org/10.1016/j.epsl.2019.01.045

Kutzbach, J.E., 1981. Monsoon climate of the early Holocene: Climate experiment with the Earth's orbital parameters for 9000 years ago. Science 214, 59-61. https://doi.org/10.1126/science.214.4516.59

Lajeunesse, P., St-Onge, G., 2008. The subglacial origin of the Lake AgassizOjibway final outburst flood. Nat. Geosci. 1, 184-188. https://doi.org/10.1038/ngeo130

Laonamsai, J., Ichiyanagi, K., Kamdee, K., 2020. Geographic effects on stable isotopic composition of precipitation across Thailand. Isotopes Environ. Health Stud. 56, 111-121. https://doi.org/10.1080/10256016.2020.171460

Laskar, A.H., Huang, J.-C., Hsu, S.-C., Bhattacharya, S.K., Wang, C.-H., Liang, M.C., 2014. Stable isotopic composition of near surface atmospheric water vapor and rain-vapor interaction in Taipei, Taiwan. J. Hydrol. 519, 2091-2100. https://doi.org/10.1016/j.jhydrol.2014.10.017

Li, D., Tan, L., Cai, Y., Jiang, X., Ma, L., Cheng, H., Edwards, R.L., Zhang, H., Gao, Y., An, Z., 2019. Is Chinese stalagmite $\delta 180$ solely controlled by the Indian summer monsoon? Clim. Dyn. 53, 2969-2983. https://doi.org/10.1007/s00382-019-04671-X

Liu, Y., Lo, L., Shi, Z., Wei, K.-Y., Chou, C.-J., Chen, Y.-C., Chuang, C.-K., Wu, C.C., Mii, H.-S., Peng, Z., Amakawa, H., Burr, G.S., Lee, S.-Y., DeLong, K.L., Elderfield, H., Shen, C.-C., 2015. Obliquity pacing of the western Pacific Intertropical Convergence Zone over the past 282,000 years. Nat. Commun. 6, 10018. https://doi.org/10.1038/ncomms 10018

Liu, Z., Kutzbach, J., Wu, L., 2000. Modeling climate shift of El Nino variability in the Holocene. Geophys. Res. Lett. 27, 2265-2268. https://doi.org/10.1029/2000GL011452

Liu, Z., Ostrenga, D., Teng, W., Kempler, S., 2012. Tropical rainfall measuring mission (TRMM) precipitation data and services for research and applications. Bull. Am. Meteorol. Soc. 93, 1317-1325. https://doi.org/10.1175/BAMS-D11-00152.1

Morrill, C., Jacobsen, R.M., 2005. How widespread were climate anomalies 8200 years ago? Geophys. Res. Lett. 32. https://doi.org/10.1029/2005GL023536

Moy, C.M., Seltzer, G.O., Rodbell, D.T., Anderson, D.M., 2002. Variability of El Niño/Southern Oscillation activity at millennial timescales during the Holocene epoch. Nature 420, 162-165. https://doi.org/10.1038/nature01194

Partin, J.W., Cobb, K.M., Adkins, J.F., Clark, B., Fernandez, D.P., 2007. Millennialscale trends in west Pacific warm pool hydrology since the Last Glacial Maximum. Nature 449, 452-455. https://doi.org/10.1038/nature06164

Pausata, F.S.R., Gaetani, M., Messori, G., Berg, A., Maia de Souza, D., Sage, R.F., deMenocal, P.B., 2020. The Greening of the Sahara: Past Changes and Future Implications. One Earth 2, 235-250. https://doi.org/10.1016/j.oneear.2020.03.002

Rohling, E.J., Pälike, H., 2005. Centennial-scale climate cooling with a sudden cold event around 8,200 years ago. Nature 434, 975-979. https://doi.org/10.1038/nature03421

Schneider, T., Bischoff, T., Haug, G.H., 2014. Migrations and dynamics of the intertropical convergence zone. Nature 513, 45-53. https://doi.org/10.1038/nature13636 
Scholz, D., Hoffmann, D.L., 2011. StalAge - An algorithm designed for construction of speleothem age models. Quat. Geochronol. 6, 369-382. https://doi.org/10.1016/j.quageo.2011.02.002

Shanahan, T.M., McKay, N.P., Hughen, K.A., Overpeck, J.T., Otto-Bliesner, B., Heil, C.W., King, J., Scholz, C.A., Peck, J., 2015. The time-transgressive termination of the African Humid Period. Nat. Geosci. 8, 140-144. https://doi.org/10.1038/ngeo2329

Shen, C.-C., Wu, C.-C., Cheng, H., Lawrence Edwards, R., Hsieh, Y.-T., Gallet, S., Chang, C.-C., Li, T.-Y., Lam, D.D., Kano, A., Hori, M., Spötl, C., 2012. Highprecision and high-resolution carbonate ${ }^{230} \mathrm{Th}$ dating by MC-ICP-MS with SEM protocols. Geochim. Cosmochim. Acta 99, 71-86. https://doi.org/10.1016/j.gca.2012.09.018

Tan, L., Li, Y., Wang, X., Cai, Y., Lin, F., Cheng, H., Ma, L., Sinha, A., Edwards, R.L., 2020. Holocene Monsoon Change and Abrupt Events on the Western Chinese Loess Plateau as Revealed by Accurately Dated Stalagmites. Geophysical Research Letters 47, e2020GL090273. https://doi.org/10.1029/2020GL090273

Tan, L., Shen, C.-C., Löwemark, L., Chawchai, S., Edwards, R.L., Cai, Y., Breitenbach, S.F.M., Cheng, H., Chou, Y.-C., Duerrast, H., Partin, J.W., Cai, W., Chabangborn, A., Gao, Y., Kwiecien, O., Wu, C.-C., Shi, Z., Hsu, H.-H., Wohlfarth, B., 2019. Rainfall variations in central Indo-Pacific over the past 2,700 y. Proc. Natl. Acad. Sci. 201903167. https://doi.org/10.1073/pnas.1903167116

Teller, J.T., Leverington, D.W., Mann, J.D., 2002. Freshwater outbursts to the oceans from glacial Lake Agassiz and their role in climate change during the last deglaciation. Quat. Sci. Rev. 21, 879-887. https://doi.org/10.1016/S02773791(01)00145-7

Thomas, E.R., Wolff, E.W., Mulvaney, R., Steffensen, J.P., Johnsen, S.J., Arrowsmith, C., White, J.W.C., Vaughn, B., Popp, T., 2007. The 8.2 ka event from Greenland ice cores. Quat. Sci. Rev. 26, 70-81. https://doi.org/10.1016/j.quascirev.2006.07.017

Tian, Z., Li, T., Jiang, D., 2017. Strengthening and westward shift of the tropical Pacific Walker Circulation during the mid-Holocene: PMIP Simulation Results. J. Clim. 31, 2283-2298. https://doi.org/10.1175/JCLI-D-16-0744.1

Tierney, J.E., Oppo, D.W., Rosenthal, Y., Russell, J.M., Linsley, B.K., 2010. Coordinated hydrological regimes in the Indo-Pacific region during the past two millennia. Paleoceanography 25, PA1102. https://doi.org/10.1029/2009PA001871

Tierney, J.E., deMenocal, P.B., 2013. Abrupt Shifts in Horn of Africa Hydroclimate Since the Last Glacial Maximum. Science 342, 843-846. https://doi.org/10.1126/science.1240411

Tierney, J.E., Pausata, F.S.R., deMenocal, P.B., 2017. Rainfall regimes of the Green Sahara. Sci. Adv. 3, e1601503. https://doi.org/10.1126/sciadv.1601503

Trenberth, K.E., Stepaniak, D.P., 2001. Indices of El Niño evolution. J. Clim. 14, 1697-1701. https://doi.org/10.1175/15200442(2001)014<1697:LIOENO>2.0.CO;2

Wang, B., Clemens, S.C., Liu, P., 2003. Contrasting the Indian and East Asian monsoons: Implications on geologic timescales. Mar. Geol. 201, 5-21. https://doi.org/10.1016/S0025-3227(03)00196-8 
Wang, P., Clemens, S., Beaufort, L., Braconnot, P., Ganssen, G., Jian, Z., Kershaw, P., Sarnthein, M., 2005. Evolution and variability of the Asian monsoon system: state of the art and outstanding issues. Quat. Sci. Rev. 24, 595-629. https://doi.org/10.1016/j.quascirev.2004.10.002

Wang, P., 2009. Global monsoon in a geological perspective. Chin. Sci. Bull. 54, 1113-1136. https://doi.org/10.1007/s11434-009-0169-4

Wang, Y., Cheng, H., Edwards, R.L., He, Y., Kong, X., An, Z., Wu, J., Kelly, M.J., Dykoski, C.A., Li, X., 2005. The Holocene Asian monsoon: Links to solar changes and North Atlantic climate. Science 308, 854-857. https://doi.org/10.1126/science.1106296

Wang, Y., Cheng, H., Edwards, R.L., Kong, X., Shao, X., Chen, S., Wu, J., Jiang, X., Wang, X., An, Z., 2008. Millennial- and orbital-scale changes in the East Asian monsoon over the past 224,000 years. Nature 451, 1090-1093. https://doi.org/10.1038/nature06692

Wang, P.X., Wang, B., Cheng, H., Fasullo, J., Guo, Z., Kiefer, T., Liu, Z., 2017. The global monsoon across time scales: Mechanisms and outstanding issues. Earth-Sci. Rev. 174, 84-121. https://doi.org/10.1016/j.earscirev.2017.07.006

Wohlfarth, B., Higham, C., Yamoah, K.A., Chabangborn, A., Chawchai, S., Smittenberg, R.H., 2016. Human adaptation to mid- to late-Holocene climate change in Northeast Thailand. The Holocene 26, 1875-1886. https://doi.org/10.1177/0959683616645947

Wu, Y., Li, T.-Y., Yu, T.-L., Shen, C.-C., Chen, C.-J., Zhang, J., Li, J.-Y., Wang, T., Huang, R., Xiao, S.-Y., 2020. Variation of the Asian summer monsoon since the last glacial-interglacial recorded in a stalagmite from southwest China. Quat. Sci. Rev. 234, 106261. https://doi.org/10.1016/j.quascirev.2020.106261 Wurtzel, J.B., Abram, N.J., Lewis, S.C., Bajo, P., Hellstrom, J.C., Troitzsch, U., Heslop, D., 2018. Tropical Indo-Pacific hydroclimate response to North Atlantic forcing during the last deglaciation as recorded by a speleothem from Sumatra, Indonesia. Earth Planet. Sci. Lett. 492, 264-278. https://doi.org/10.1016/j.epsl.2018.04.001

Yancheva, G., Nowaczyk, N.R., Mingram, J., Dulski, P., Schettler, G., Negendank, J.F.W., Liu, J., Sigman, D.M., Peterson, L.C., Haug, G.H., 2007a. Influence of the intertropical convergence zone on the East Asian monsoon. Nature 445, 74-77. https://doi.org/10.1038/nature05431

Yancheva, G., Nowaczyk, N.R., Mingram, J., Dulski, P., Schettler, G., Negendank, J.F.W., Liu, J., Sigman, D.M., Peterson, L.C., Haug, G.H., 2007b. Influence of the intertropical convergence zone on the East Asian monsoon. Nature 445, 74-77. https://doi.org/10.1038/nature05431 
Fiqure $1-6$
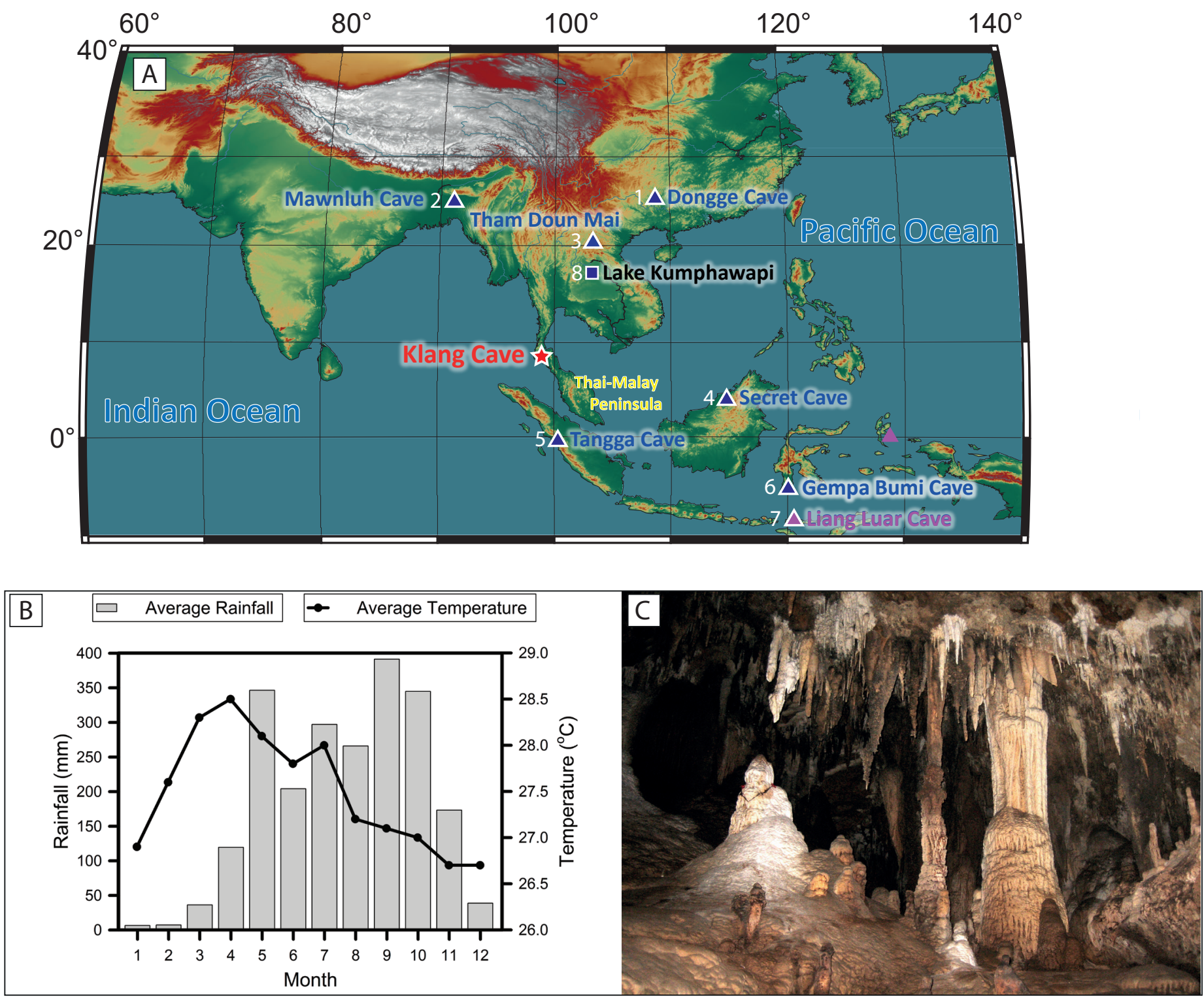
Figure 2

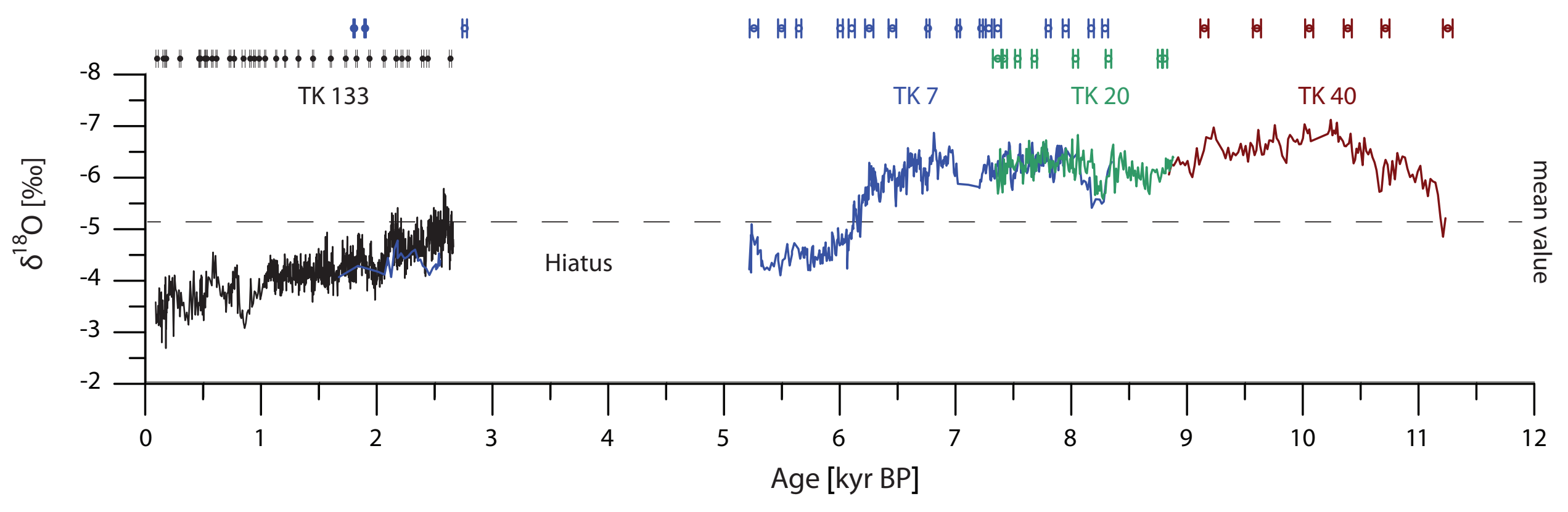


Figure 3

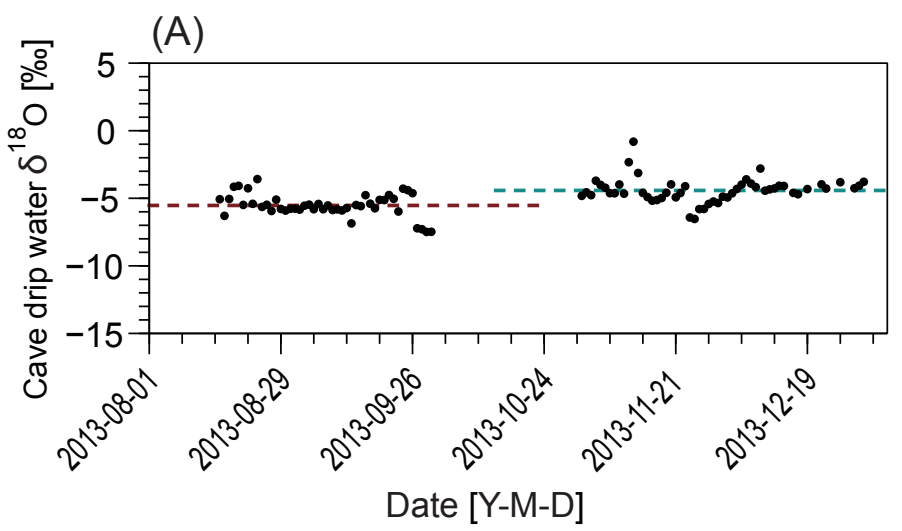

(B)
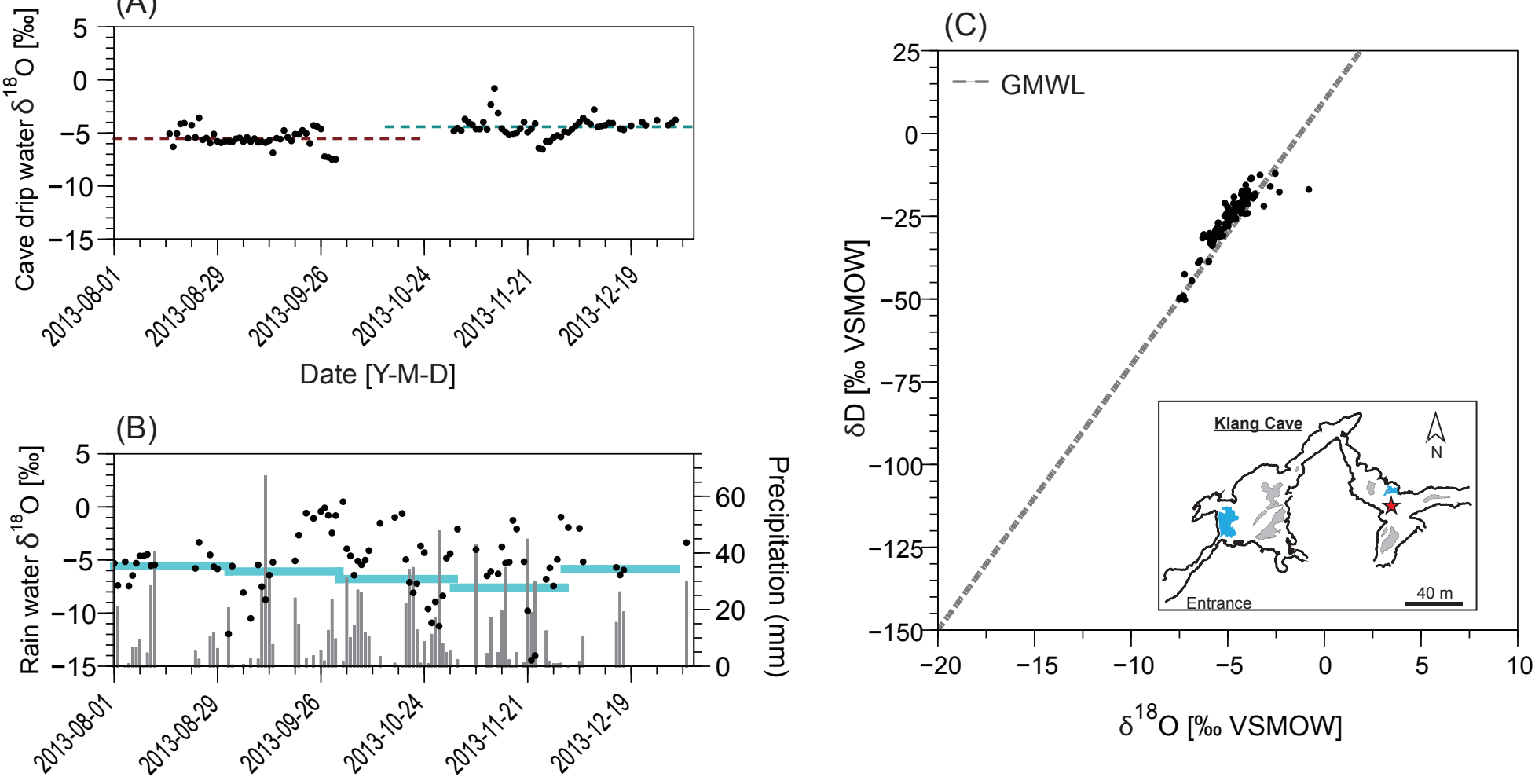

Date [Y-M-D] 
Figure 4

(A) Dongge Cave

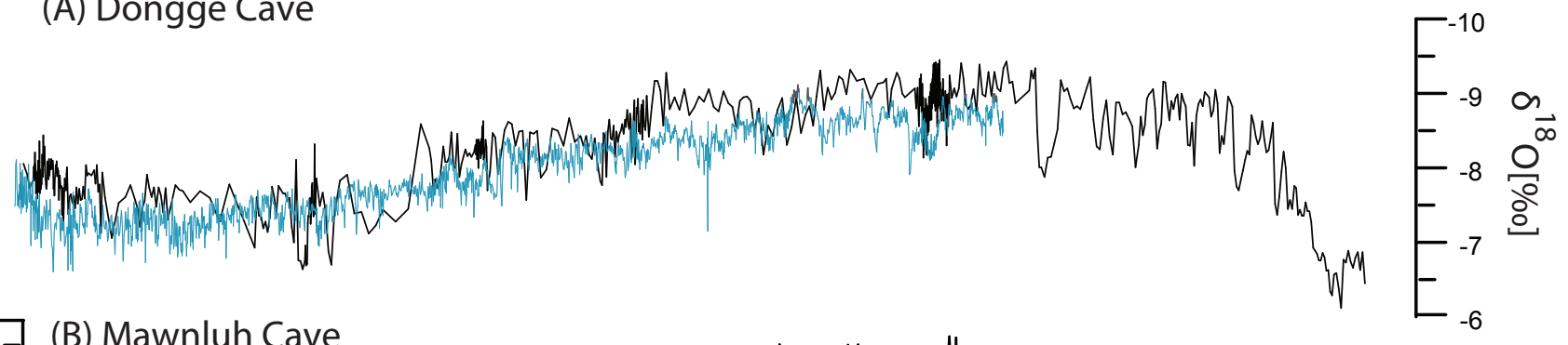

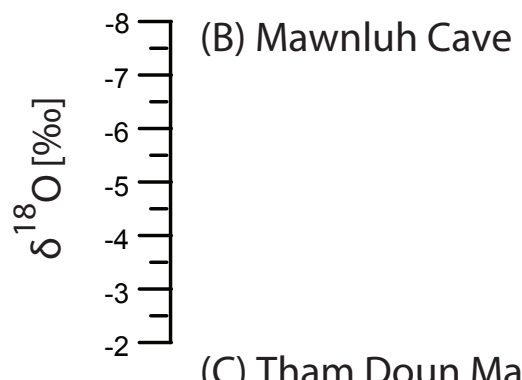

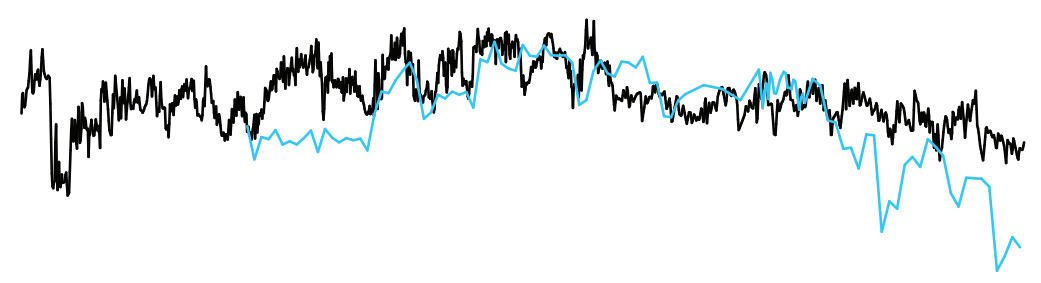

(C) Tham Doun Mai Cave

$$
\text { Tham Doun Mai Cave }
$$
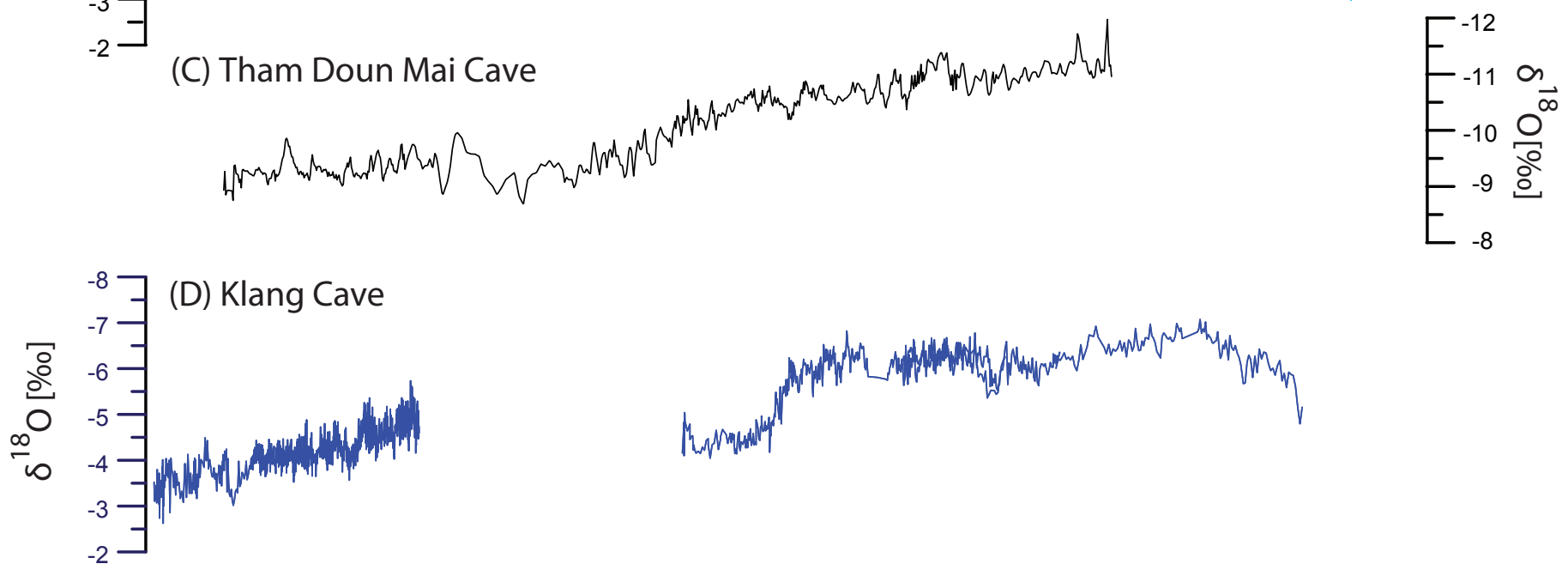

$$
\begin{aligned}
& \text { (E) Secret Cave } \\
& \text { (F) Tangga Cave }
\end{aligned}
$$

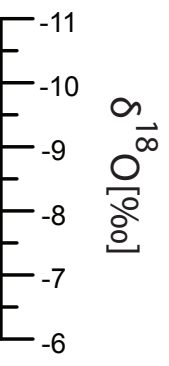

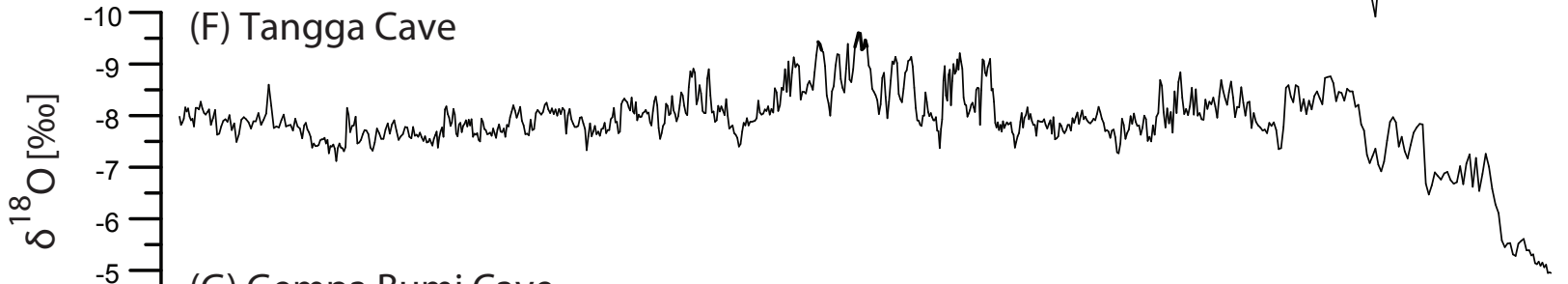
- (G) Gempa Bumi Cave

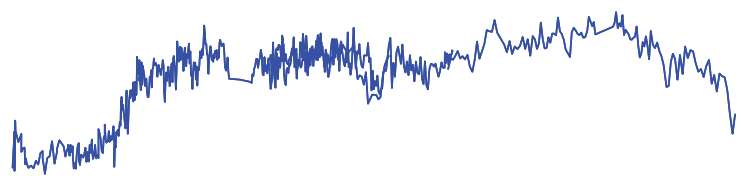

(H) Liang Luar Cave

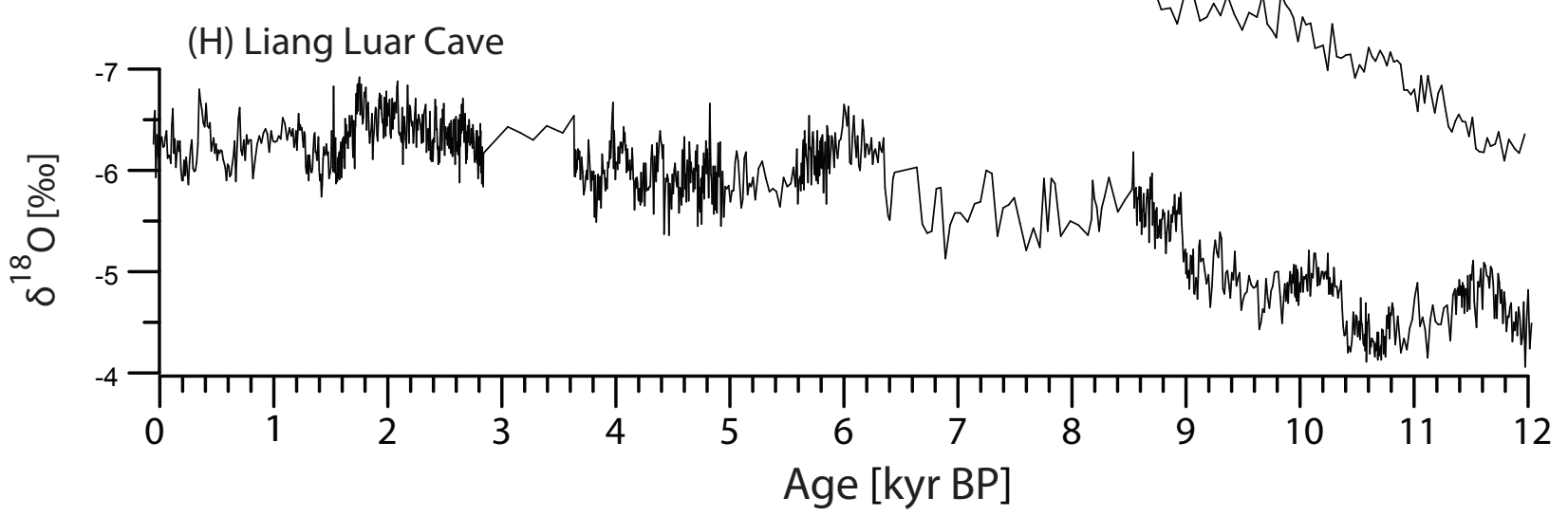



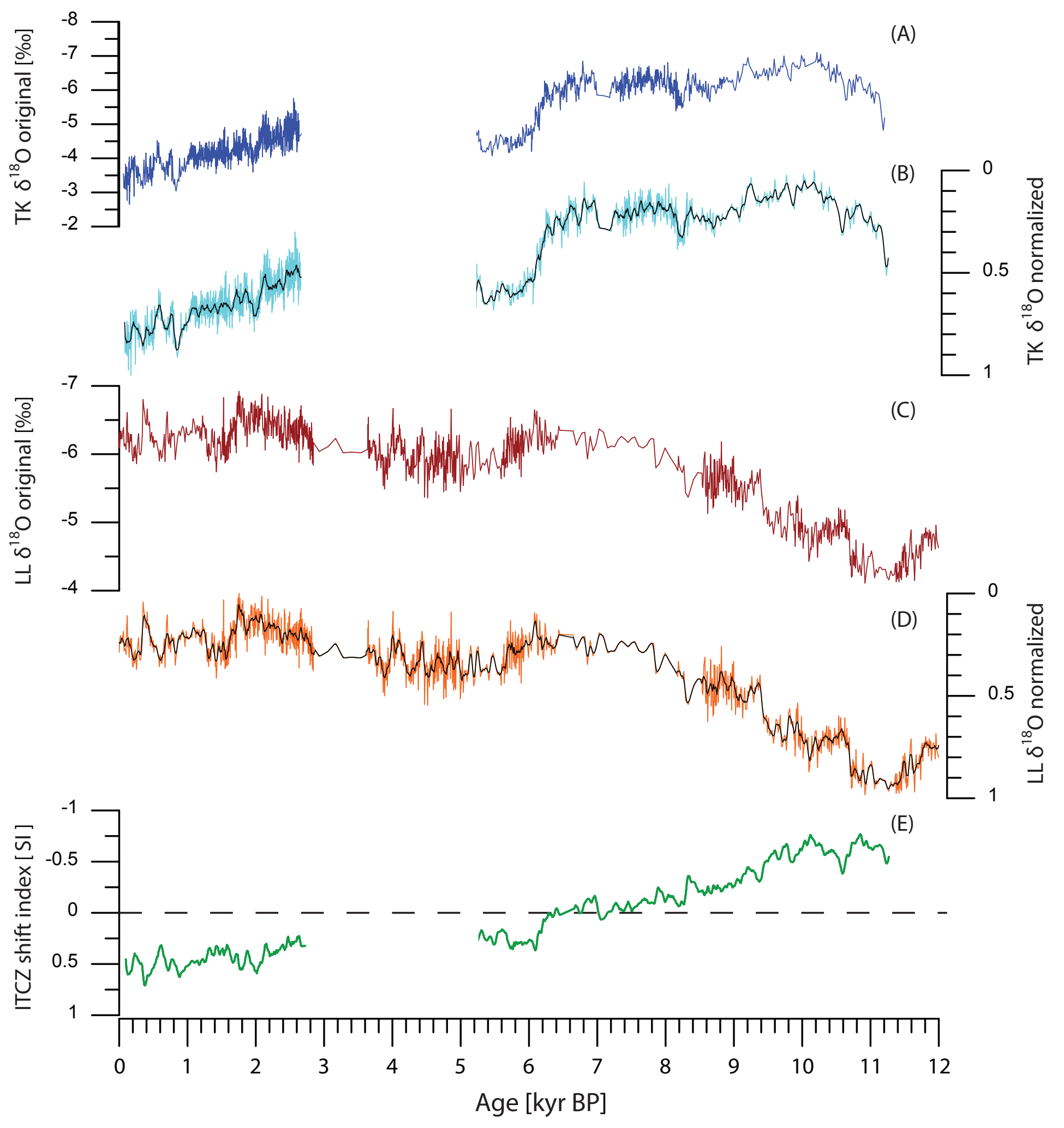
Figure 6

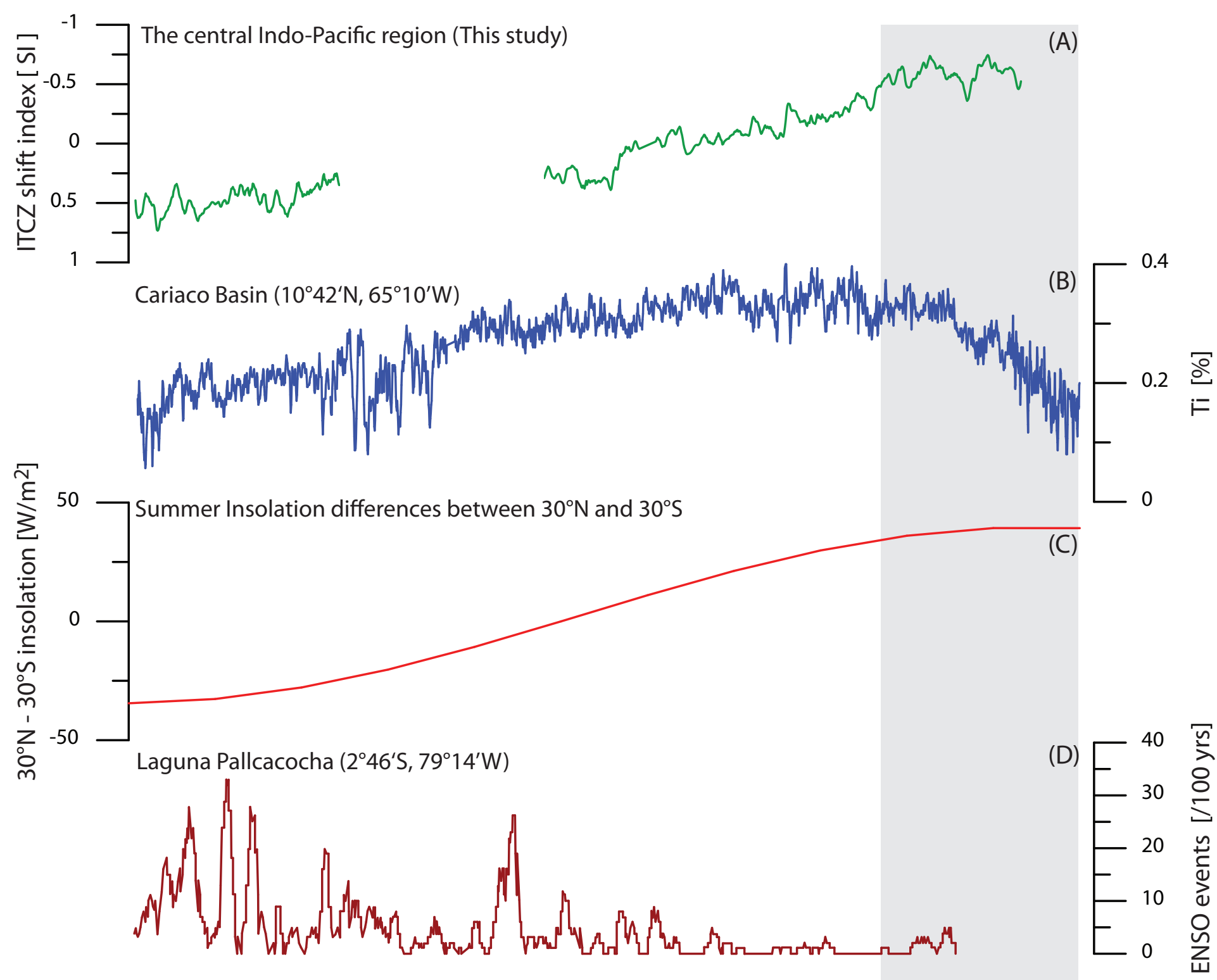

Iberian margin core SU8118 $\left(37^{\circ} 46^{\prime} \mathrm{N}, 10^{\circ} 11^{\prime} \mathrm{W}\right)$

(E)

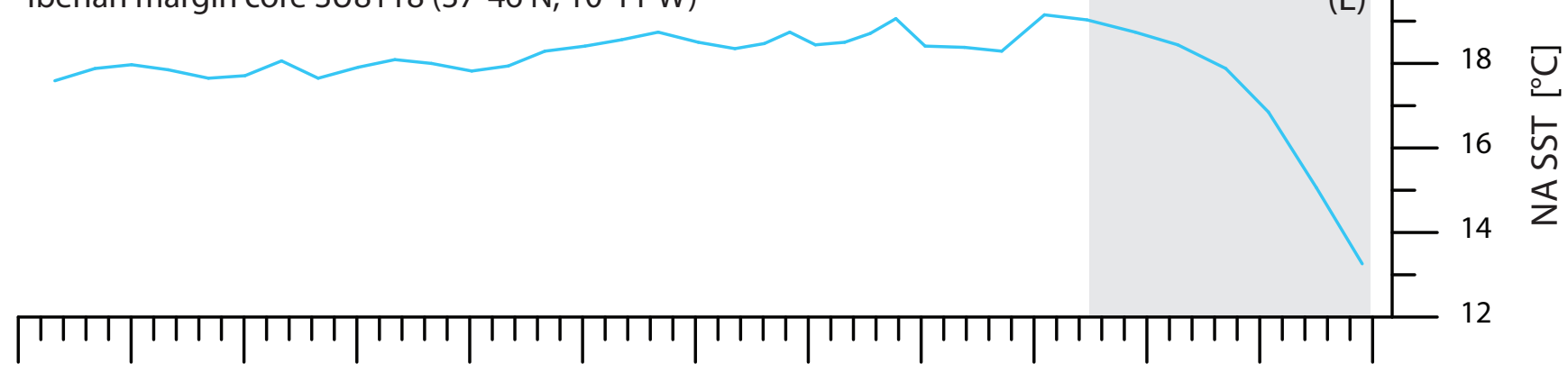

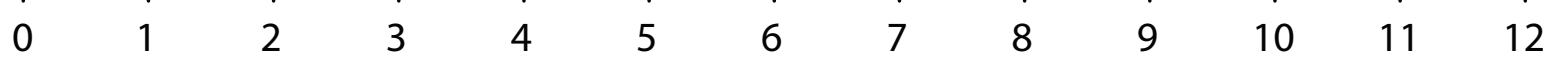

Age $[k y r$ BP] 
Click here to access/download Table

Table 1 6November2020.xIsx 


\section{Declaration of interests}

\The authors declare that they have no known competing financial interests or personal relationships that could have appeared to influence the work reported in this paper.

The authors declare the following financial interests/personal relationships which may be considered as potential competing interests: 


\section{Author statement}

C-C.S. and B.W. supervised the project and provided resources. S.C. wrote the original draft and made all figures with help from L.T., C-C.S. and B.W. S.C., L.L. and C-C.S. investigated and conducted a field survey and sampling. S.C. and H-C.W. performed sample preparation and Hendy Test. H-C.W., T-L.Y., Y.-C.C. and H-S.M. did U-Th dating and isotope analysis. G.L., M.B. and S-Y.G contributed some ideas and helped to improve the manuscript. All authors discussed the results, reviewed and edited the manuscript. 


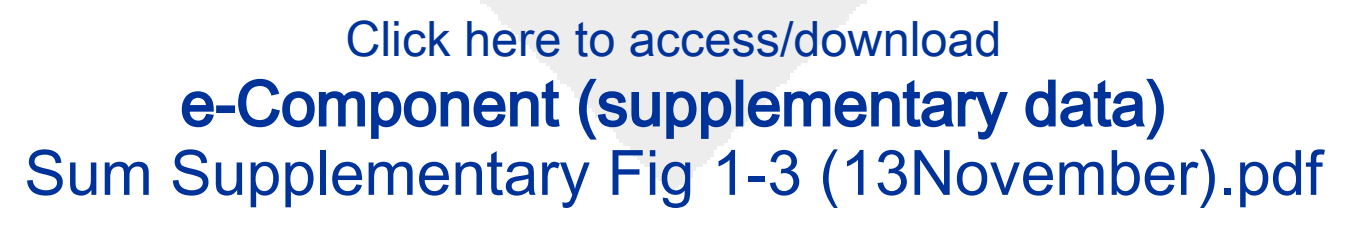




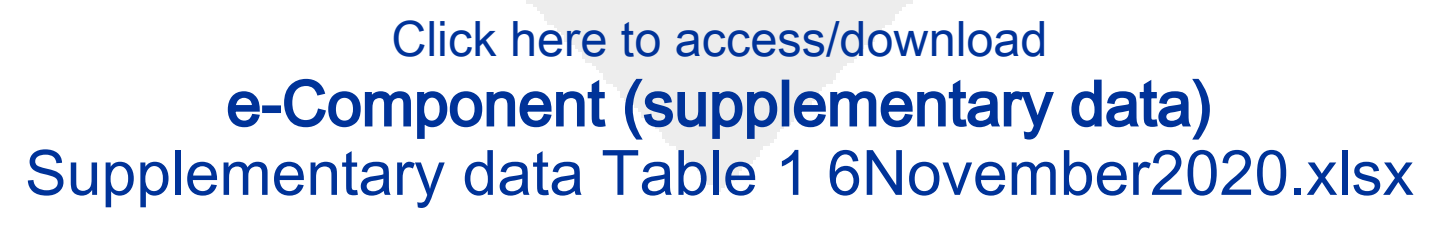

Click here to access/download e-Component (supplementary data) Supplementary data Table 16 November2020.xlsx 